\title{
THE INTER-RELATIONSHIPS
}

\section{OF \\ FLAGELLATA \& PRIMITIVE ALGE.}

\author{
By FRANK CAVERS, D.Sc., F.L.S. \\ Lecturer in Botany at Goldsmiths' College, \\ University OF LONDON.
}

NEW PHYTOLOGIST REPRINT, No. 7 .

LONDON :

WESLEY \& SON, ESSEX STREET, STRAND, 1913. 



\section{CONTENTS.}

Page.

I.-INTRODUCTION...

II.-General Characters of the Flagellata $\ldots$... 3

III.-Chloromonads And Heterokontae ("Confervales,"

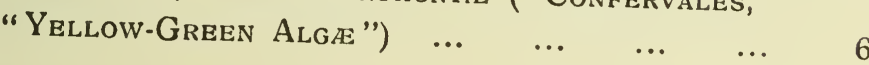

IV.-Relation of Green Alge to Chlamydomonads $\quad \ldots \quad 10$

$\begin{array}{llllllllll}\text { V.-Volvocales } \ldots & \ldots & \ldots & \ldots & \ldots & \ldots & \ldots & 10\end{array}$

$\begin{array}{llllllllll}\text { VI. -The Chrysomonads } & \ldots & \ldots & \ldots & \ldots & \ldots & 20\end{array}$

VII.-The Cryptomonads and Their Relationships $\ldots .27$

VIII.-The Peridiniales (Dinoflagellata) and Their

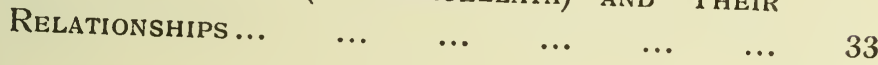

IX.-Conclusion... $\quad \ldots \quad$.

Literature Referred To $\quad \begin{array}{lllllllll}\text { Re } & \ldots & \ldots & \ldots & \ldots & \ldots & 46\end{array}$

$\begin{array}{llllllllll}\text { Addendum... } & \ldots & \ldots & \ldots & \ldots & \ldots & \ldots & \ldots & 52\end{array}$ 
Digitized by the Internet Archive in 2016

https://archive.org/details/interrelationshi00cave 
THE INTER-RELATIONSHIPS OF FLAGELLATA

AND PRIMITIVE ALGA.

By.F. Cavers.

\section{I-INTRODUCTION.}

LTHOUGH the phylogeny of the lower Algre has been treated $A$ in some detail in various recent works, such as those by Oltmanns (95), Lotsy (89), and West (146), a merely casual perusal of the rapidly increasing literature dealing with these and other lowly organisms suffices to show that even in the most recent general treatises, whether botanical or zoological, there are many gaps-apart from the fact that such text-books of necessity become more or less out-of-date as soon as they have been published. It is perhaps inevitable that botanical writers are inclined to overlook, or at any rate fail to appreciate fully, the researches of zoologists on the vast assemblage of unicellular organisms now conveniently designated as "Protista," while the zoologists have perhaps erred in the past by definitely claiming as animals a considerable number of organisms which are regarded by botanists as definitely vegetable in nature despite their possession of certain animal-like characters.

As is aptly remarked by Willey and Hickson (151) in their recent work on the Mastigophora (Flagellata) in Lankester's Treatise on Zoology - "It was formerly a question whether such an order of Mastigophora should be reckoned among the unicellular Algr or among the Protozoa, but this controversy is now practically over, and biological disquisitions upon the group are equally at home in zoological and botanical treatises and journals." The same view has also been expressed by various other writers, and the study of the Flagellata and other unicellular organisms has within recent years emerged as a distinct and rapidly growing branch of biological investigation-" Protistology"-though, in the nature of things, its scope is defined very differently by different biologists. In the wide sense, the Protista include all unicellular. organisms, whether they be regarded as definitely animal, definitely vegetal, evenly balanced in characters between the two kingdoms, or transitional between the ill-defined Protista (in the narrow sense) on one hand and either of the two main kingdoms on the other.

It is hoped that the following brief slietch of the possible interrelationships between certain groups of Flagellata, primitive Algæ, and certain groups of Protozoa may be useful to students of both Botany and Zoology, and to this end a tolerably extensive bibliography has been compiled in order to indicate the sources from which the material has been drawn and to which the reader may be referred for details that could not be included in this necessarily condensed summary.

Just twenty years ago, Klebs (67) published the first comprehensive work on the Flagellata in which these organisms-usually treated by zoological writers as a division of the Protozoa-were studied in detail from the botanical as well as the zoological point of view. Klebs pointed out that the Flagellata are a heterogenous assemblage in which, more than in any other Protista, the formal distinctions hitherto drawn between the animal and vegetable kingdoms entirely vanish; that the Flagellata may

be regarded as a central group from which the various classes of 
Protozoa have arisen; and that this group also embraces a number of specialised lines of descent-including several distinct lines leading to the lower Algæ. The results of recent work, some of which it is proposed to summarise and discuss here, have in the main confirmed the views expressed by Klebs in his diagrammatic scheme of the phylogenetic relationships between Flagellata and Algæ-with certain modifications arising from the discovery of new forms and the reinvestigation of forms whose structure and development had been imperfectly known-and have led to great advances in our linowledge of the phylogeny of the Algæ, and to striking changes in the classification of the Green Algæ in particular.

It is now generally recognised that a division of the Flagellata into forms referable to the vegetable kingdom (forms bearing chlorophyll, having a cell-rvall of cellulose, and having no mouth or other means for ingesting solid food) and forms referable to the animal kingdom (forms without chlorophyll, without a cell-wall or with a wall not consisting of cellulose, and having a mouth or other means for solid ingestion) would be absolutely unnatural and could only be made by ignoring genetic relationships which are perfectly obvious. Moreover, such a division would leave out of account a large number of organisms which could not logically be placed in either division. A better criterion would seem to be afforded by the consideration that in the lowest organisms regarded as animals, sornatic growth and reproduction by fission are marlied by active mobility, the flagellate cells growing and dividing in this condition; whereas in the lowest organisms regarded as plants, somatic growth and division are marlsed by stability, and the flagellate cells do not grow and divide but may conjugate and give rise to a sedentary zygote. We shall see, however, that even this criterion-which has led to the inclusion by zoological writers of the greater part or even the whole of the Flagellata in the animal kingdom as a class of the Protozoa--is vitiated by the occurrence of transitional forms through which certain Flagellate groups shade off almost imperceptibly into definitely Algal organisms.

Assuming that the lower Algæ have arisen from a Flagellate ancestry, the work of the majority of recent writers on the phylogeny of the Algæ has been directed towards the tracing of the lines of descent leading from certain Flagellate groups to the lower Algæ, and to the formulation of a system of classification which shall reflect the phylogenetic relationships thus disclosed. Of the four main groups into which the Algæ have usually been divided, the Blue-green Algæ are probably related in some way to the Bacteria, but the origin and affinities of both divisions of "Schizophyta" are quite uncertain, though they are possibly of Flagellate ancestry ; the Green Algæ may be traced, through transitional forms, to at least two distinct sources among the green Flagellata; the Brown Algæ have similarly been shown, especially by quite recent work, to have arisen from certain Flagellata with brown chromatophores; while as regards the Red Algæ there appears at present to be no better-founded view than that suggested by Klebs-that they may have arisen from Brown Algæ.

In recent speculations concerning the evolution of plants it has generally been assumed that the earliest vegetable organisms. possessed chlorophyll and were autotrophic (photosyntheticy) 
forms, their immediate ancestors being autotrophic Flagellates; that the Green, the Brown, perhaps also the Red, and more doubtfully the Blue-green Algæ arose respectively from similarly coloured Flagellata; and that the various groups of Fungi have arisen independently from different Algal forms-though some fungal series may have come directly from Flagellata. However, Vuillemin (144) has pointed out that in our ignorance concerning the conditions under which the earliest forms of life appeared, we are hardly justified in assuming that photosynthetic organisms necessarily preceded heterotrophic organisms in time, and that from this point of view the nitrogen-fixing Bacteria have as good a claim as chlorophyll-bearing organisms to be regarded as the nearest living representatives of the earliest forms of life. We cannot, however, construct a series of existing forms connecting the Bacteria with the main autotrophic Algal phyla, though it has been suggested (Doflein, 40 ; Zuelzer, 158) that the Bacteria may have given rise, through the Spirochætes, to the Flagellata.

Starting from simple coloured autotrophic organisms, Brunnthaler (17) argues that the Red Algæ are the most ancient group of plants, on the grounds that (i) the earliest plants were in all probability free-swimming Flagellate forms, and no such forms occur among the present-day Red Algæ; (ii) the rad pigment of the Rhodophyceæ is an adaptation to life in the deeper waters of the sea and in the dim light of the primitive world with its dense cloud canopy, since this pigment absorbs the rays in which that light would be rich; (iii) the present-day Red Algre show hardly any primitive types, and motile free-swimming reproductive cells are absent from the group. The Brown Alga would come next; that this is a younger group is indicated by the great diversity in structure of the reproductive organs, the constant presence of flagellate reproductive cells, and the adaptation of the brown pigment to the absorption of light more closely approaching in quality that of the bright sunlight reaching the surface of the present world, but still with an atmosphere richer in water vapour than that of to-day. Meanwhile, the primitive Red Algæ had become adapted to the dim ancient light, and therefore restricted to the deeper sea, leaving the upper waters as an open field for the evolution of the new brown seaweed population. The Green Algæ, finally, are the youngest group to appear in the succession outlined by Brunnthaler, their green colour being an adaptation to the fuller light (richer in the less refrangible rays of the spectrum) of modern times; the early forms were marine, but after possessing the upper waters of the sea and invading estuaries they became adapted also for life inland in fresh water. According to Brunnthaler, there is no direct relationship between the presentday Algæ and Flagellata, though the earlier Flagellates may have given rise to the Red Algæ; the living Flagellata he regards as the termination of an ancient series of organisms which have evolved independently of the Algx.

\section{II-General Characters of the Flagellata.}

Without dealing further with such questions as these, it may be noted in passing that there is a good deal to be said against the assumption, which has frequently been made, that the Flagellata represent the most primitive of known organisms; this claim may 
perhaps quite as reasonably be put forward for bacterial forms or for the simpler amœboid types of Protozoa. For instance, there are grounds for regarding a flagellum as a specialised type of pseudopodium, since between the blunt pseudopodium of an Amoba and the vibratile flagellum of a typical Flagellate there are various intermediate forms of protoplasmic outgrowth concerned in loco. motion or ingestion of food or other functions. In any case, however, the Flagellata appear to include forms leading by a series of transitional types to the lower Green and Brown Algæ, and these are our chief concern here.

The characters given by Klebs as distinguishing the Flagellata from the motile unicellular Green Algæ-the Chlamydomonads, which are still included by zoological writers in the Flagellata under the name "Phytoflagellata"-may be enumerated as follows. Body unicellular or a colony of cells, cell uninucleate with a thick or thin external layer of protoplasm-the periplastin which anoeboid chnages of form may take place. Outside this a non-living investment of the cell is frequently present, of varied form and often not closely adherent to the body. Specialised anterior end of clear protoplasm bearing one or more flagella. Organism alvays remaining capable of movement. Nutrition either holozoic (solid food being taken by pseudopodia, through a specialised mouth, or otherwise), saprophytic, or holophytic. In the last case the chromatophores are green or yellow-brown, and may take the form of bands, plates, or discs. True pyrenoids entirely absent. Paramylum, leucosin, or a fatty oil the visible anabolites (products of assimilation). Starch entirely absent. Reproduction by simple longitudinal fission, usually beginning at the anterior end of the body. Individual always capable of forming resting cysts. Gamogenesis apparently entirely absent.

It may be noted that recent work has made it extremely difficult to frame a definition of the Flagellata which shall separate this group sharply from the Protozoa on one hand and the lower. Algæ on the other. Exceptions have to be admitted in connexion with almost every character hitherto given in definitions of the group. The body usually has a definite anterior end from which one or more flagella arise, but in Multicilia the numerous flagella spring from various points of the spherical body; the flagella are usually motile and unbranched organs, but in certain Chrysomonads they are non-motile and even branched, corresponding with the pseudopodia of various Protozoa; the visible product of anabolism is usually either oil or leucosin or paramylum, but starch is formect in certain Chrysomonadinere (e.g., Cryptomonas) and in the Polyble.e pharidacere (if these be regarded as Flagellates rather than Chlany; domonadine Algæ); the great majority are uninucleate, but the Trypanosomes have two nuclei, while Multicilia lacustris is describe as having a large number; as a rule, division is longitudinal anc. occurs in the motile phase, but it is sometimes transverse (e.g., Oxyrrhis, Stylochrysalis) and it may occur exclusively in a resting state; sexual reproduction is usually absent, but a sexual process has been shown to occur in various genera belonging to different groups of Flagellata $(39,50,118,121)$.

In Senn's account (135), which was published in 1900, the Flagellata fall into seven divisions. Three of these comprise only colour- 
less heterotrophic forms (with holozoic, saprophytic, or parasitic nutrition), while the members of the remaining four divisions are normally provided with pigments which make holophytic nutrition possible, though many of these are also capable of heterotrophic nutrition and may therefore be described as "mixotrophic." In the lowest of the colourless groups in Senn's arrangement, the Pantostomatinere, any portion of the body can ingest solid food by means of pseudopodia, while in all the remaining forms capable of holozoic nutrition such ingestion occurs only at certain definite points; the Pantostomatinean genus Multicilia has a spherical protoplast with numerous radially arranged flagella, but in all other Flagellata the body shows radial or bilateral symmetry, or may be asymmetrical, and the number of flagella is more limited. According to Senn, the Pantostomatinex have given rise to the lower Protozoa (Sarcodina); to the small Flagellate group Distomatinex with irregular bilateral symmetry and paired groups of flagella-this group forming a blindly-ending line; and to the very large group Protomastiginex which comprises about half of the known genera of Flagellata and shows great variety in form and structure. The Protomastiginex may be regarded as the common source of the Infusoria, Mycetozoa, Sporozoa, and perhaps also the Bacteria, on one hand, and of the four groups of pigment-bearing or "Algal " Flagellata on the other. Of these latter, the Chrysomonadinea and the Cryptomonadinex are, according to Senn, closely related but of independent origin; the. Chrysomonadinex have brown chromatophores, produce oil and leucosin, and show affinities with the Brown Algx and the Diatoms, while the Cryptomonadineæ produce starch, are variously coloured or in some cases colourless, and may have given rise to the Peridiniales and the Green Algæ. The two remaining groups, Chloromonadinez and Euglenineæ, differ from the other groups in having numerous green chromatophores; there is a more definite periplast or firm outer protoplasmic layer; the contractile vacuoles are so situated and co-ordinated as to form a pulsating system opening at a definite point on the exterior ; the product of assimilation is oil (Chloromonadineæ) or paramylum (Euglenineæ). In the Chloromonadiner, which Senn derives from Monas- and Bodo-like forms among the Protomastigineæ, the contractile vacuoles are aggregated at the anterior end of the cell and open to the exterior by a pore. Senn regards the Chloromonadinex as being too highly organised to serve as the starting-point for an Algal group as suggested by Luther and others (see below); but they have by further elaboration of the cell given rise to the Eugleninex, a blindly-ending line repre. senting the highest type of organisation found in the Flagellata and decidedly showing no Algal affinities, whatever may be said of the Chloromonadinex. The Eugleninex have, as compared with the Chloromonads, a more definite, often striated, and highly resistant periplast, and a gullet-like canal leading to a deep-seated vacuole into which a system of small and actively contractile vacuoles is drained.

Apart from Senn's compilation, the more comprehensive accounts of the Flagellata are contained in zoological worlss (18, $19,37,40,93,139,151)$, and much of the recent literature on the "Algal" forms is published in zoological journals. The Peridiniales will be dealt with in this review, since this group includes decidedly Flagellate forms, and reference will also be made to certain other 
groups (e.g., Cystoflagellata, Silicoflagellata, Coccolithophoridæ) not classed by Senn among the Flagellata, though they occupy this position in zoological systems of classification. On the hand, the Trypanosomes and the majority of the other specialised or heterotrophic Flagellata need not be considered in a discussion of the origin of Algæ from Flagellata.

In the following pages, it is proposed, taking as a startingpoint the treatment of Algal groups in Engler and Prantl's Pflanzenfamilien and that of the Flagellata in the same,work and in the more comprehensive zoological treatises, to review briefly the advances that have recently been made in our knowledge of certain lines of descent leading from Flagellata through transitional forms to the simpler Algæ. Restricting our speculations to such series as appear to include what may be fairly considered as transitional forms, we can recognise three main lines, leading (i) from the simpler Chloromonads to the Heterokontæ or Yellow.green Algæ; (ii) from the Polyblepharids to the Chlamydomonads and thence to the Isokontæ and other Green Algæ; and (iii) from the Chrysomonads and Cryptomonads to the Brown Algæ, the Peridiniales, and probably certain other groups.

\section{ill-Chloromonads and Heterokontae ("Confervales," "Yellow-Green Alge").}

Until recently the Green Algæ have usually been divided into Conjugatæ, Protococcoideæ, Confervoideæ, and Siphoneæ-the division made, for instance, by Wille in Engler and Prantl's Pflanzenfamilien in 1890, and adhered to, with slight modifications, in that writer's recent supplement on the Chlorophycex in the same work (150). The Conjugatæ form a natural group, marked by the absence of ciliated reproductive cells-whence the name Akontre given to the group in the modern system of Green Algæ based in part upon the ciliation of the asexual reproductive cells or zoogonidia-and by the siphonogamic sexual process of conjugation by means of a tube formed by the fusion of processes from the two gametangia. The limits and arrangement of the three remaining classes have, however, been considerably modified, owing chiefly to considerations advanced in publications by Chodat, Bohlin, Luther, and Blackman.

In all Green Algæ excepting the Conjugatæ (Alkontæ), the zoogonidia and zoogametes are typically pear-shaped cells bearing at the anterior end a number of flagella. In most cases there are two (occasionally four) flagella of equal length inserted at the same. point (Isokontæ); in the small order CEdogoniales the motile cells have a circlet of numerous flagella (Stephanokontr); while in the Confervales there are two flagella of unequal length (Heterokontæ) in some forms the shorter flagellum may, apparently, be absent. It may be added that in the attempts that have been made to connect Algal series with corresponding Flagellate series, the number and insertion of the flagella are not the sole criteria used, various other characters being taken into account. In certain groups of Flagellata, e.g., the Eugleniner, the flagella show considerable differences in genera which are obviously related closely to each other as judged by other cytological characters. When due attention is paid to the tout ensemble of characters, however, there can be little doubt that the flagellum characters (number, insertion, 
relative length where two or more are present) may afford a valuable clue to affinities.

In 1899, Luther (90) described a new genus, Chlorosaccus (Fig.

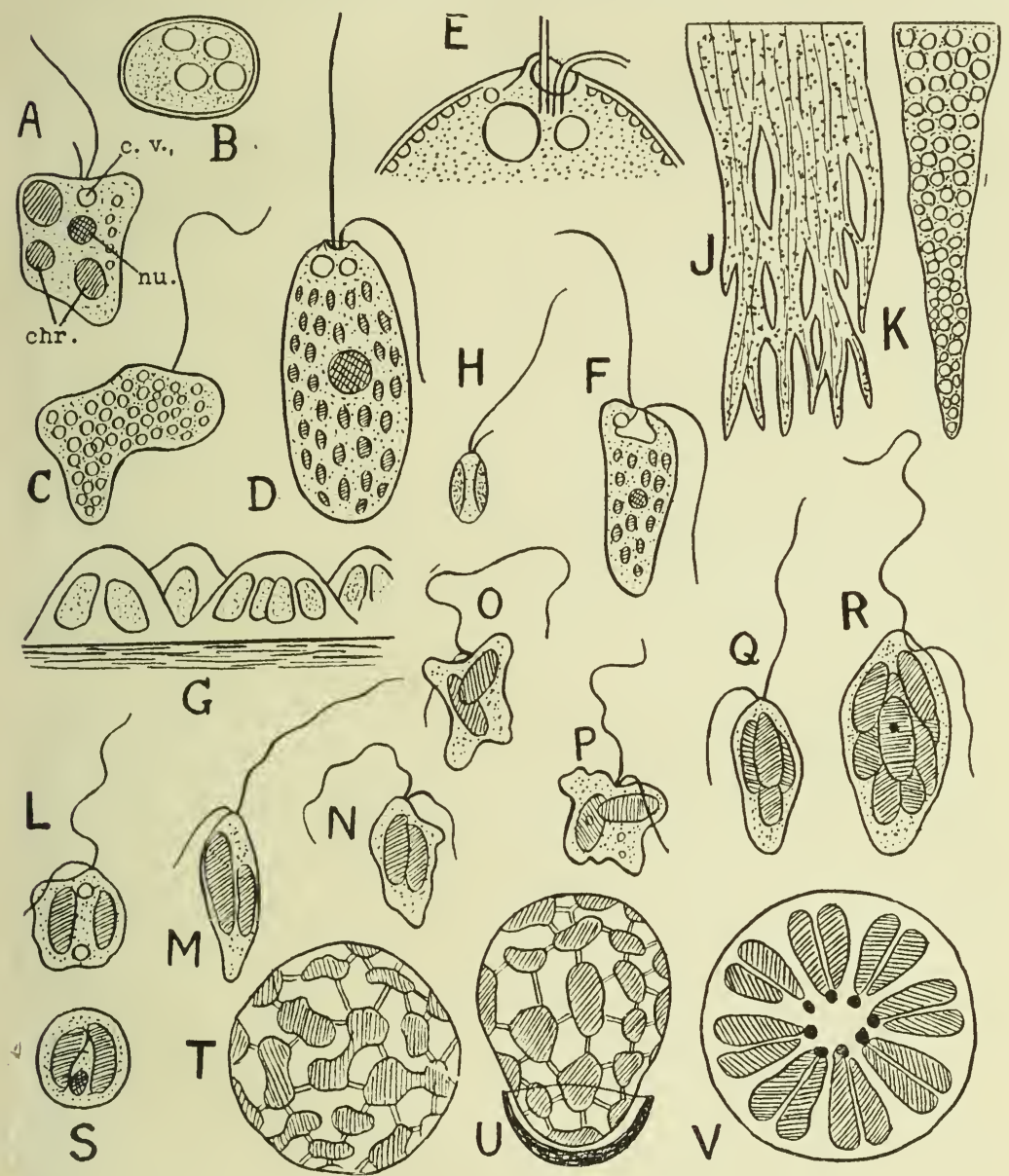

Fig. 1. CHLOROMONADINEAE (Flagellate and Transitional Heterokontæ). A to C, Chloramoba heteromorpha Bohl.: A, a normal green individual, with nucleus, contractile vacuole, three chromatophores, and oil-drops; $\mathrm{B}$, resting cyst; C, amœboid colourless individual. D, E, Vacuolaria vivescens Cienk.: E shows the anterior end more highly magnified, with two vacuoles and insertion of flagella in the gullet-like pit. F, Vacuolaria flagellata Senn. G, H, Chlorosacus fluidus Luther; $\mathrm{G}$, portion of a colony; $\mathrm{H}$, motile cell. $\mathrm{J}$ to $\mathrm{V}$, Leuvenia natans Gardner ; $J$, a portion of the floating colony ; $K$, the same more highly magnified; L, a motile cell soon after being set free; $M, N, O, P$, later stages showing amœeboid habit of the zoogonidia; $Q$ and $R$, zoogonidia with four and eight chromatophores respectively; $S$, resting zoogonidium with the flagella withdrawn and with a cell-wall developed; a free floating colony showing the rapidly dividing chromatophores held together by protoplasmic threads ; U, an earlier stage in development of colony, showing the ruptured cyst-wall at base; $\mathrm{V}$, section through a young colony showing the nuclei and the chromatophores in pairs.

A-C from Bohlin; D, E, from Senn; F, from Stokes; G, H, from Luther ; J-V, from Gardner. 
$1, \mathrm{G}, \mathrm{H})$, which is of great importance as forming a connecting link between the Chloromonad genus Chloramaba (Fig. 1, A-C) on one hand and the Algal group "Confervales" on the other. This group had been previously founded as a distinct series of Green Algæ as the result of the work of Borzi $(14,15)$ and of Bohlin $(10)$ on various genera which had formerly been included in the old groups of Protococcoidex, Confervoideæ, and Siphoneæ. These genera differ from other Green Algæ in several characters besides the possession by the motile cells of two unequal flagella-namely, the presence of a large proportion of xanthophyll or carotin in their chromatophores (hence the name "Yellow-green Algæ" has been given to the group) which are typically numerous and discoid; the production of oil instead of starch as the visible anabolite; and the curious structure of the cell-wall in some genera, e.g., the unicellular Ophiocytium in which the upper part of the wall becomes detached like a lid, and the filamentous Tribonema in which each cell is bounded by the halves of two $\mathrm{H}$-shaped pieces and the whole filament readily breaks up into fragments of this shape. Luther and Bohlin concluded that these forms had arisen independently of the remaining Green Algæ, from the simpler types of the Flagellate group Chkoromonadinex, e.g., Chloranceba, through a transitional form like Chlorosaccus. On the other hand, Chlorambaa leads through forms like Vacuolaria (Fig. 1, D-F) to the more specialised Chloromonadinex and doubtless to the Eugleniner, which need not be further considered here.

The genus Leuvenia (Fig. $1, \mathrm{~J}$ to $\mathrm{V}$ ), recently described by Gardner (48), appears to be related to Chlorosaccus and to form an interesting additional link in the chain connecting Chloramaba with the "Convervales." The motile cells are at first pear-shaped, with two unequal flagella and two ovoid curved green chromatophores (sometimes becoming four or eight by division); later the cell hecomes amœboid. Growth occurs in a resting condition-the motile cells come to rest, float to the surface of the water, become spherical, withdraw their flagella, and grow rapidly in size; then the nucleus divides into as many as twenty, the chromatophores divide by constriction, and finally the whole interior divides up into, zoogonidia, each appropriating two chromatophores and a nucleus. Under certain conditions the resting cells secrete a gelatinous substance causing them to adhere together in stringy floating masses, in which they become spherical; and in this palmella stage division into zoogonidia occurs as in the ordinary growth. stage.

Pascher (112) has recently described a new genus of Heterokontæ (Psendotetraëdron, which superficially resembles the Proto. coccaceous genus Tetraëdron but shows characteristic Heterokontan features-numerous discoid yellow-green chromatophores, production of oil instead of starch, cell-wall consisting of two portions fitting upon each other like a box and its lid.

Adopting the terminology suggested by Pascher (113), the following arrangement of the Heterolontæ may be proposed. It will be noted that the group is here divided into a serres of orders which show a striking parallelism with the corresponding divisions of the Isokontie. The genera of the Isokontan groups are omitted. 


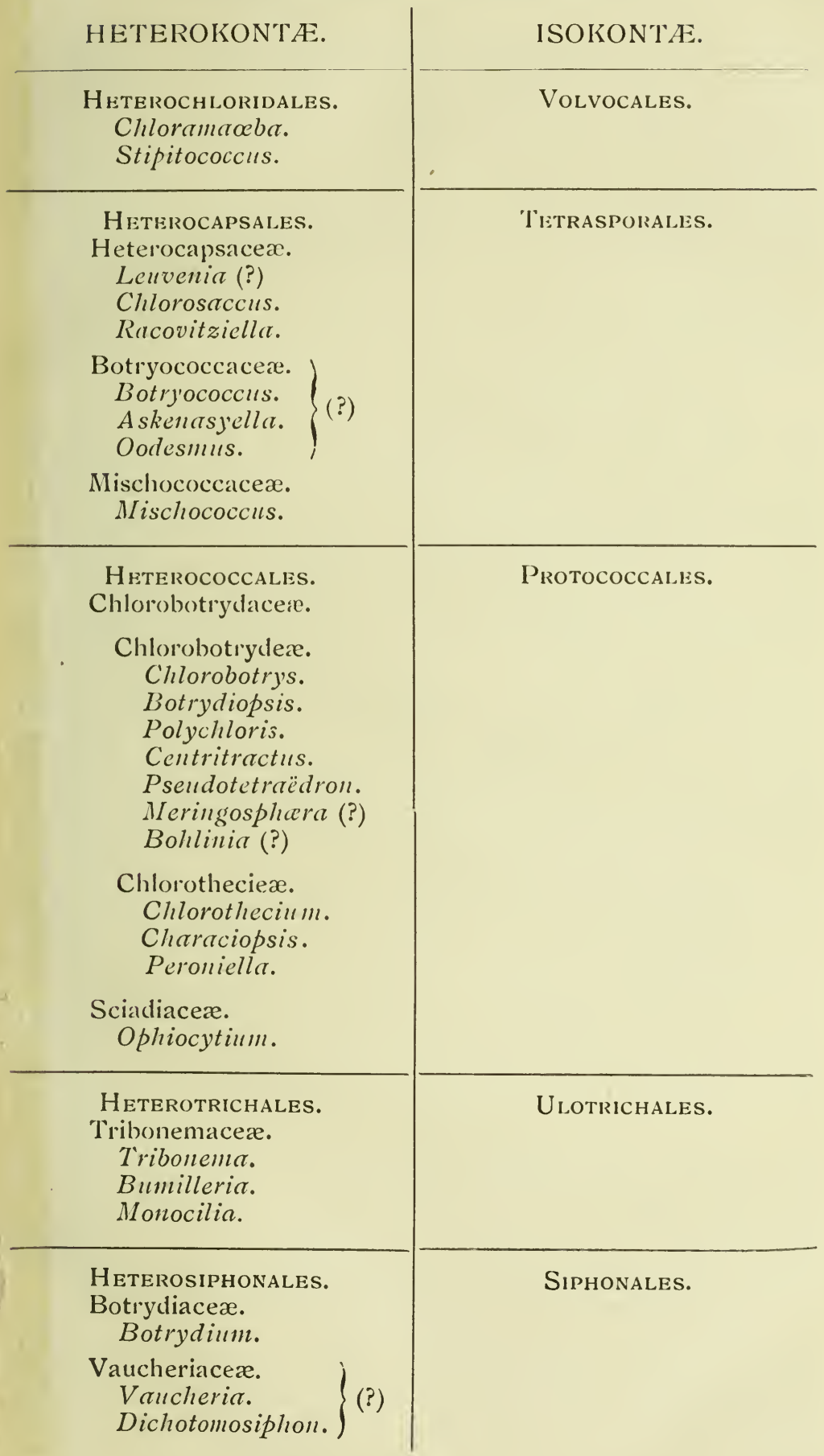




\section{IV.-Relation of Green Alge to Chlanydononads.}

7 THERE appears to be strong support for the view that the 1. majority of the Green Algæ may be derived from Flagellate ancestors with two or more equal flagella. In 1897, Chodat (24) pointed out that in the life-history of the lower Green Algæ there may be distinguished three conditions, either of which may become dominant, the other two being then transient or suppressed: (i) the zoospore condition or motile stage; (ii) the sporangium condition or unicellular motionless stage; (iii) the palmelloid condition, in which non-motile cells are connected into aggregates by cell-walls at right angles to each other. In 1900, Blackman (6) published an important paper on the phylogeny of the Algæ, containing not merely a critical summary of modern work bearing upon the problem, but also various far-reaching suggestions as to the lines along which the evolution of the different Algal groups may be traced from Flagellata. Blackman pointed out that among the simple Green Algæe which constitute the group of Protococcoidere three divergent vegetative tendencies are observed: (i) a Volvocine tendency towards the aggregation of motile vegetative cells into gradually larger and more specialised motile cœnobia; (ii) a Tetrasporine tendency towards the formation of aggregations by the juxtaposition of the products of septate vegetative cell-division to form non-motile organisms of increasing definiteness and solidarity; (iii) an Endosphærine tendency towards the reduction of vegetative division and septate cell-formation to a minimum. The simplest forms showing any one of these tendencies seem clearly to diverge from species of the genus Chlamydomonas, which may be regarded as the phylogenetic starting-point of the various lines of Green Algal descent. The line arising from the Volvocine tendency leads to the Volvocales and culminates in Volvox; the outcome of the Endosphrine tendency is seen in the Siphoner; while the Tetrasporine line has given rise to the great majority of the Green Algæ and through these to the Archegoniatze and other higher plants.

The phylogeny of the Conjugatr, Edogoniales, and a few other isolated groups of filamentous Green Algæ remains in some doubt, owing to the absence of practicable transitional forms connecting these groups with either the Tetrasporine line on one hand or with distinct Flagellate ancestors on the other. For further details regarding the phylogeny of the Green Algæ, reference should be made to the paper by Blackman already mentioned (6), and to the 
classification based by Blackman and Tansley (7) upon the principles set forth in that paper; also to the systematic works on Algæ by Oltmanns (95), West (146), and Lotsy (89), in which due prominence is given to modern views of Algal phylogeny. More recently, Fritsch (46) has published a valuable paper, in which is included a useful bibliography; while Pavillard (115) has contributed a resumé of some modern work on Vegetable Protistology-though his "revue rapide" omits entirely the Brown Flagellata and lower Brown Algæ, on which some remarkably interesting work has been published during the last few years.

The relationships of the three lines of Flagellate-Algal descent here suggested are indicated in the accompanying Table A, a fuller explanation of which will be given later.

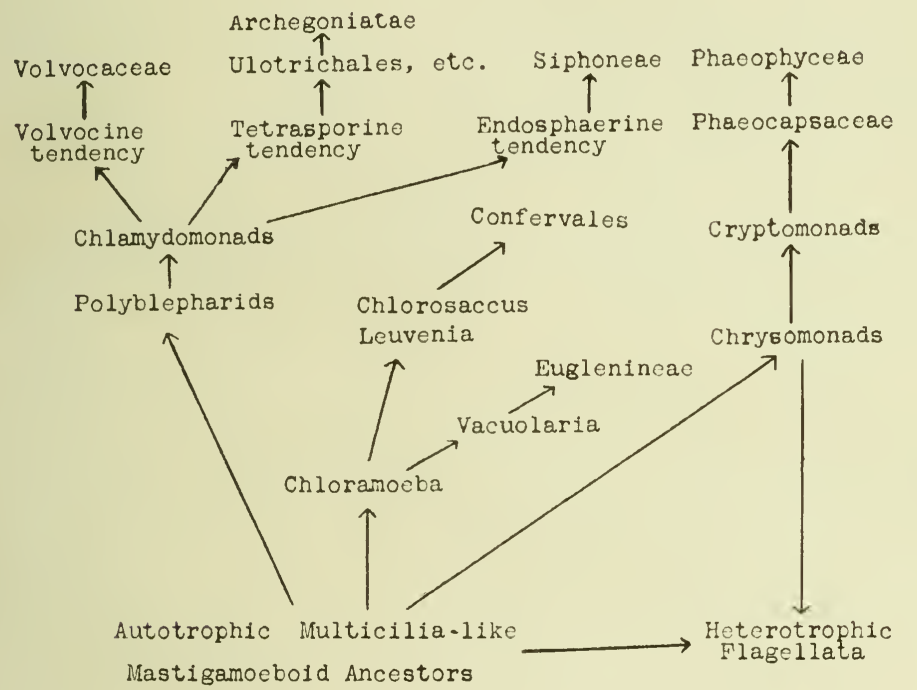

Table A.-Suggested Phylogeny of (I) the Polyblepharid and Chlamydomonad, (II) the Chloromonad, and (III) the Chrysomonad and Cryptomonad lines. For details see text.

Since 1900 , perhaps the greatest advances in the study of those Flagellates which are more obviously important in connexion with the phylogeny of the Algæ have been made among the Chrysomonads and Cryptomonads, but before dealing with these we may consider some interesting additions to our knowledge of the group of Green Algæ whose evolution from the Flagellata has, on the whole, been most completely worked out-namely, the Volvocales, using this name to include the entire series of organisms (the "Phytoflagellata" of various zoological writers) representing the transition from Flagellate ancestors to the motile unicellular Green Algæ (Chlamydomonads) and the outcome of the Volvocine tendency which leads to the formation of increasingly complex motile coenobia and culminates in Volvox. 


\section{V.-Volvocales.}

The Polyblepharidacex are included in the Volvocales by Blackman and Tansley (7), Wille (150), and various other writers, though Fritsch (46) regards them as still belonging to the Flagellata, but it appears quite immaterial how this family is placed in a formal scheme of classification, so long as it is recognised that no sharp line of division separates the Flagellata from the lower Algre and that this remarkable transitional family shows an extraordinarily even balance between the two groups. The Polyblepharids agree with typical Flagellates in being devoid of a definite cellulose wall and in undergoing longitudinal division in the motile phase-but it should be noted that in several genera of Volvocales (Chlorogonium, Brachiomonas, and even colonial genera like Gonium and the oogamous Eudorina) division may occur while the flagella are still motile. The Polyblepharids have the characteristic basin-shaped Volvocine chromatophore and a pyrenoid, but-as will appear later-the Cryptomonads and some of the other Chrysomonadinex would have as much right to a position among the Algæ as have the Polyblepharids if the possession of Algal chromatophores, pyrenoids, starch, and a firm periplast allowing of only slight changes of shape be talsen as definitely Algal characters; while, on the other hand, the fact that sexual reproduction occurs in a Polyblepharid (Dunaliella) cannot now be regarded as an argument against the reference of this family to Flagellata rather than to Algæ.

Probably the most primitive genus of Polyblepharidaceæ is Polyblepharis (Fig. 2, A), in which the broader anterior end of the conical body bears from six to eight flagella in a tuft; in Pyramimonas (Griffiths, 52; Fig. 2, B, C) there are four flagella arising from a depression at this end, which is four-lobed, as is also the chromatophore; in Chloraster (Fig. 2, D) there is a central fifth flagellum; while in Tetratoma, a somewhat doubtful and incompletely known form, there are four flagella inserted at separate points on the anterior half of the spherical body. The genus Dunaliellu (Fig. 2, $\mathrm{E}$ to $\mathrm{L})$, recently described by Hamburger (53) and by Teodoresco $(140,141)$, evidently forms a transition from the Polyblepharidaceæ to the Chlamydomonads, since it has only two flagella and shows conjugation of isogamous zoogametes; while Stephanoptera, recently discovered by Dangeard (35), resembles Pyramimonas in structure but has only two flagella, thus connecting Pyramimonas with Dunaliella-according to Dangeard, the life-cycle of Stephanoptera ends in encystment, the cyst having sometimes two nuclei instead of one, but the fate of the cyst was not determined. To the Polyblepharidaceæ probably also belongs the genus Chlorodendron (Fig. 2, $M$ to B), placed by Oltmanns (95) in a special family (Chlorodendraceæ), with the closely related, or perhaps congeneric, forms Prasinocladus lubricus Kuckuck and Euglenopsis subsalsa Davisthese have recently been investigated by Dangeard $(34,36)$ who regards these forms as being closely related to the Carteriaceæ (see below). In the Chlorodendrex, branching colonies are produced by the localised secretion of mucilage derived from the periplast, or cell-ivall, of the dividing cells, and this family, or sub-family, forms 
an interesting side-line of colonial development arising from a Pyramimonas-like type.

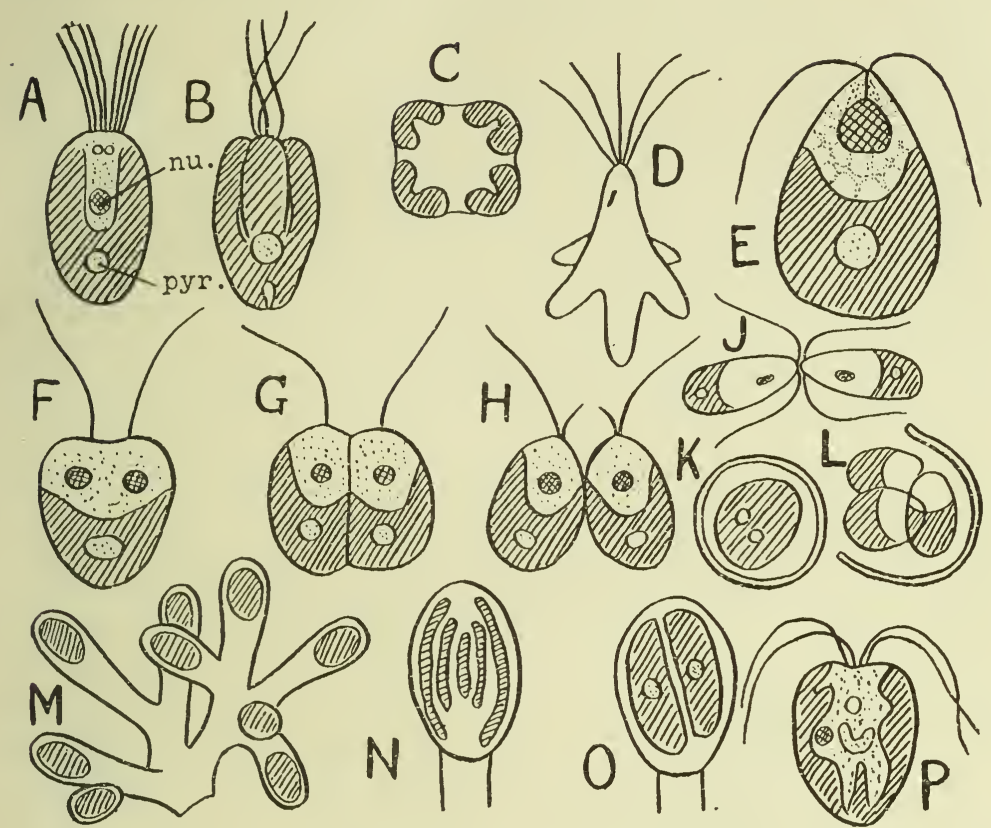

Fig. 2. POLYBLEPHARIDACEAE.-A, Polyblepharis singularis Dang. $\mathrm{B}, \mathrm{C}$, lyramimonas delicutulus Griffiths: C, anterior view showing extremities of lobes of chromatophore. D, Chloraster gyrans Ehrb., showing stigma or " eve spot." E to L, Dunaliella salina (Dun.) Teodor.: E, vegetative cell, with bell shaped chromatophore, large nucleus, and reticulate protoplasm ; F, G, H, stages in division ; J, conjugation of zoogametes; $\mathrm{K}$, zygospore ; L, rupture of zjgospore to set free the zoospores. NI to P, Chlorodendron lubricum (Kuck.; Senn : M, a portion of a colony ; N, a single cell of same ; O, division of cell; P, motile cell or zoogonidium. A fiom Dangeard; B, C, from Griffiths ; D) from Stein; E and J, from Hamburger; F, G, H, K, L, from Teodoresco, M to P, from Kuckuck.

In setting forth a new classification of the Volvocales, Pascher (108) has adopted the suggestions made by Oltmanns as to the affinities between Carteria and Spondylomorum, and by Schmidle as to those between Spharelli and Stephanosphara, and has separated these genera from the remaining Volvocales, dividing this order into the four families, Polyblepharidaceæ, Carteriaceæ, Sphærellaceæ, and Chlamydomonadacex. Wollenweber (153) has suggested that the Volvocine line shows progressive reduction in the number of flagella and of contractile vacuoles, hence Carteria and Spharella may be regarded as more primitive than the Chlamydomonads, the former in having four flagella and the latter in having numerous contractile vacuoles (as many as sixty in S. Drobakensis). It is, however, rather difficult to determine just which cytological characters should be regarded as relatively primitive and which as relatively advanced among the Volvocales. For instance, numerous 
contractile vacuoles are found not only in Spharella but also in Chlorogonium (which differs from the Polyblepharids and most of the simpler Chlamydomonads in showing transverse instead of longitudinal division), and in $A g l o \ddot{e}$, a form with somewhat specialized cell structure. Carteria and Spondylomorum agree in having four flagella and in other characters, but though Carterio is usually stated to have a pyrenoid, Jacobsen (61) has described a species (C. ovata) which has none; according to this writer, Spondylomorum is also without a pyrenoid; while Chloromonas is distinguished from its ally Chlamydomonas solely on the ground that it lacks a pyrenoid, but this simply means that systematists have described pyrenoidless species or even varieties (Serbinow, 137) of Chlamydomonas as belonging to a distinct genus-on other grounds, there is little doubt that Chlamydomonas and Chloromonas are quite unnatural genera, and will probably have to be revised and split up as the result of further investigations. Most of the Volvocales have a single pyrenoid, but in C'hlamydomonas inharens (Bachmann, 3) two or three of these bodies may be present, while in $C$. coccifera (Goroschankin, 51, iii) there are five to eight pyrenoids; two occur in Spharella Drabakensis and in Stephanosphara, while Spharella pluvialis, Chlorogonium, and Pleodorina have a large number of pyrenoids.

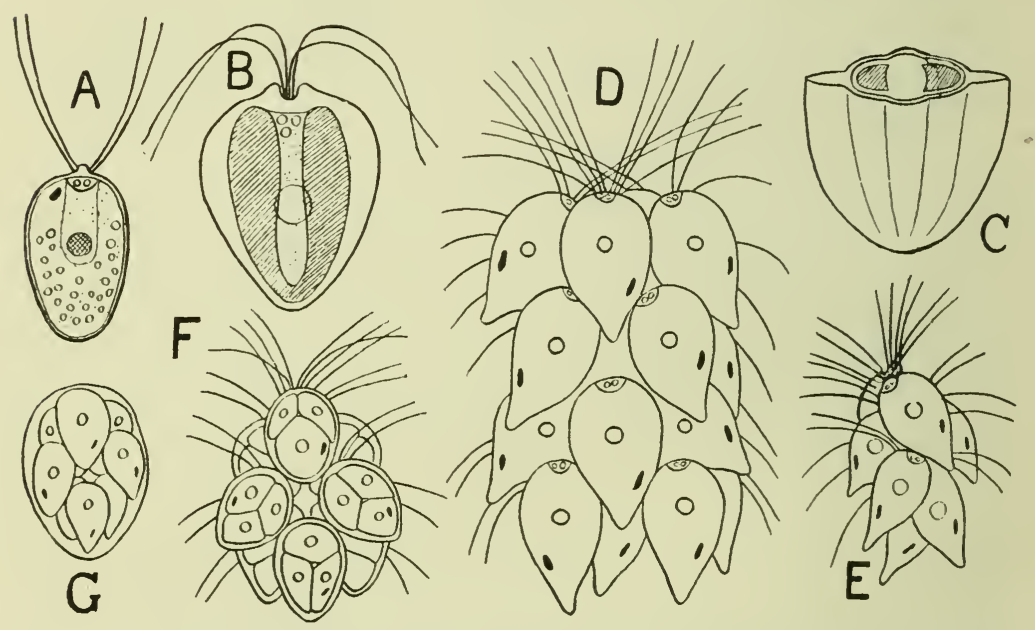

Fig. 3. CARTERIACEAE.-A, Carteria ovata Jacobsen : this species has no pyrenoid, the chromatophore contains numerous small starch grains. B, C, Scherffelia phacus Pascher: C shows the cell cut across, to make clearer the wing-like expansion of the cell-wall and the structure of the U-shaped chromatophore. D to $\mathrm{G}$, Spondylomorum quateruarium Ehrb.: D, a normal sixteen-celled cœnobium; E, an eight celled cœnobium; F, division of each cell to form a daughter cœnobium; G, daughter cœenobium not yet set free from mother-cell. A, D to $G$, from Jacobsen; B, C, from Pascher.

The family Carteriaceæ includes Carteria (Fig. 3, A), which has a very thin wall; Scherffelia (Fig. $3, \mathrm{~B}, \mathrm{C}$ ), in which the cell is flattened, oval in outline and slightly biconvex in cross-section, 
with a thick wall which in one species is produced into a marginal wing on either side, two chloroplasts which may or may not be united behind to form a U-shaped structure (obviously derived from splitting of an originally basin-shaped chromatophore), and no pyrenoid; Tetrablepharis, a colourless saprophytic form probably derived from Carteria ; and Spondylomormm (Fig. 3, D to G), a colonial form constructed on a plan quite different from that seen in the coenobial Chlamydomonadacere and consisting of sixteen Carteria. like cells in four alternating tiers of four cells each, attached to a gelatinous rod-like axis. Among the Carteriacer, sexual reproduction is only known in one or two species of Carteria which produce isogamous zoogametes. It is of interest to note that the symbiotic "Zoochlorella" found in the Planarian worm Convoluta roscoffensis (Keeble and Gamble, 65) is a species of Carteria ; the single species of Spondylomorum (S. quaternarium), hitherto known only from Europe and Asia, has recently been discovered by Campbell (20) in California.

Apart from the Polyblepharidacex and Carteriacex, the Volvocales have a pair of flagella, though a single flagellum occurs in a species of Polytoma (Pascher, 108) and in the genus Mastigo. spliara. The Sphærellacex, including the unicellular Spliarella (Hamatococcus) and the colonial Stephanosphara, are distinguished from the remaining Volvocales-the Chlamydomonadacer-mainly by the peculiar structure of the cell-wall. Various contributions to the knowledge of Spharella have recently been made, especially by Peebles (116), Reichenow (119), and Wollenweber (152, 153). What has usually been taken for a thin outstanding cell-wall is in reality a firm outer layer, while the supposed sap-containing space between wall and protoplast is a thick inner gelatinous coat, traversed by fine branching pits into which protoplasmic threads extend. Reichenow has minutely studied the structure and mitotic division of the nucleus and the shifting of the originally longitudinal axis of division into an oblique or transverse position. The chloroplast is a spongy and reticulate structure, and in $S$. pluvialis there are numerous pyrenoids at the nodes of the network. Though Sphcerella has been so much worked at, Miss Peebles appears to have been the first to observe a sexual process in this genus; she states that when dry encysted cells of $S$. pluvialis are moistened and exposed to strong light, the contents of the cyst divide into eight to sixty-four gametes which fuse in pairs, as is also the case in Steplianosphara. 
$\mathrm{F}^{\mathrm{F}}$ the unicellular Chlamydomonadacer, Chlorogonium (Fig. 4, $\mathrm{F}, \mathrm{G}, \mathrm{H}$ ) is probably on the whole the nost primitive. In its elongated spindle-like form, this genus differs from the majority of the Volvocales, but an approach to the same shape is seen in C'arteria obtusa, and the zoogametes of Stephanosphcera are spindleshaped. In Chlorogonizum the cell divides transversely to form a row of four daughter-cells, but these at once become elongated and slide past each other, acquiring the spindle form. Transverse division occurs in some species of Chlamydomonas (Fig. 4, B), though here, as in Spharella, division is originally longitudinal and there is rotation of the dividing protoplast. In Chlorogonium the chloroplast is ill-defined and spongy and varies considerably in form, being in some cases ring-like or even spiral, hence symmetrical halving can be attained without the longitudinal division which is apparently essential in forms with a basin-shaped chloroplast; there are numerous (up to sixty) pyrenoids and about a dozen contractile vacuoles (Jacobsen, 61). Cercidinum resembles Chlorogonium, but has only two pyrenoids and two vacuoles. Other simple forms are Chlamydomonas (Fig 4, A to D) and Chloromonas, the former with pyrenoids (typically one, but sometimes more) and the latter with none. Pascher's new genus Aglö̈ (Fig. 4, E) is allied to these forms, but its chloroplast is peculiar in structure, resembling two conical flasks placed base to base and being $\mathrm{H}$-shaped in optical section, with a pyrenoid in the middle of the transverse plate-like portion, and there are numerous contractile vacuoles. Gloomonas is an imperfectly known genus, probably allied to Chloromonas but with several chloroplasts. Various other genera have been described which probably represent offshoots from the Chlamydomonas type, though some of them are imperfectly known. Thus, Coccomonas (Fig. 4, J, K) appears to differ from Chlanydomonas chiefly in having a greatly thickened wall, often four-angled; Pteromonas (Fig. 4, L, M) is also thick-walled, the wall projecting as two lateral wings, as in the Carteriaceous genus Scherffelia; while Phacotus has a sculptured wall consisting of two loosely connected valves which separate to let the daughter-cells escape. Another elaboration is seen in Brachiomonas (Fig. 4, P, Q) and Lobomonas (Fig. 4, M, N); in the former the cell has a pointed posterior process and from its rounded anterior end there spring four recurved processes, in the latter the ovoid cell is produced into several rounded wart-like out-growths. In Brachiomonas (Fig. 4, $\mathrm{R}, \mathrm{S}$ ) the daughter-cells acquire the form of the parent before escaping (Teodoresco, 140; VWest, 147); as pointed out by 
Volvocales.

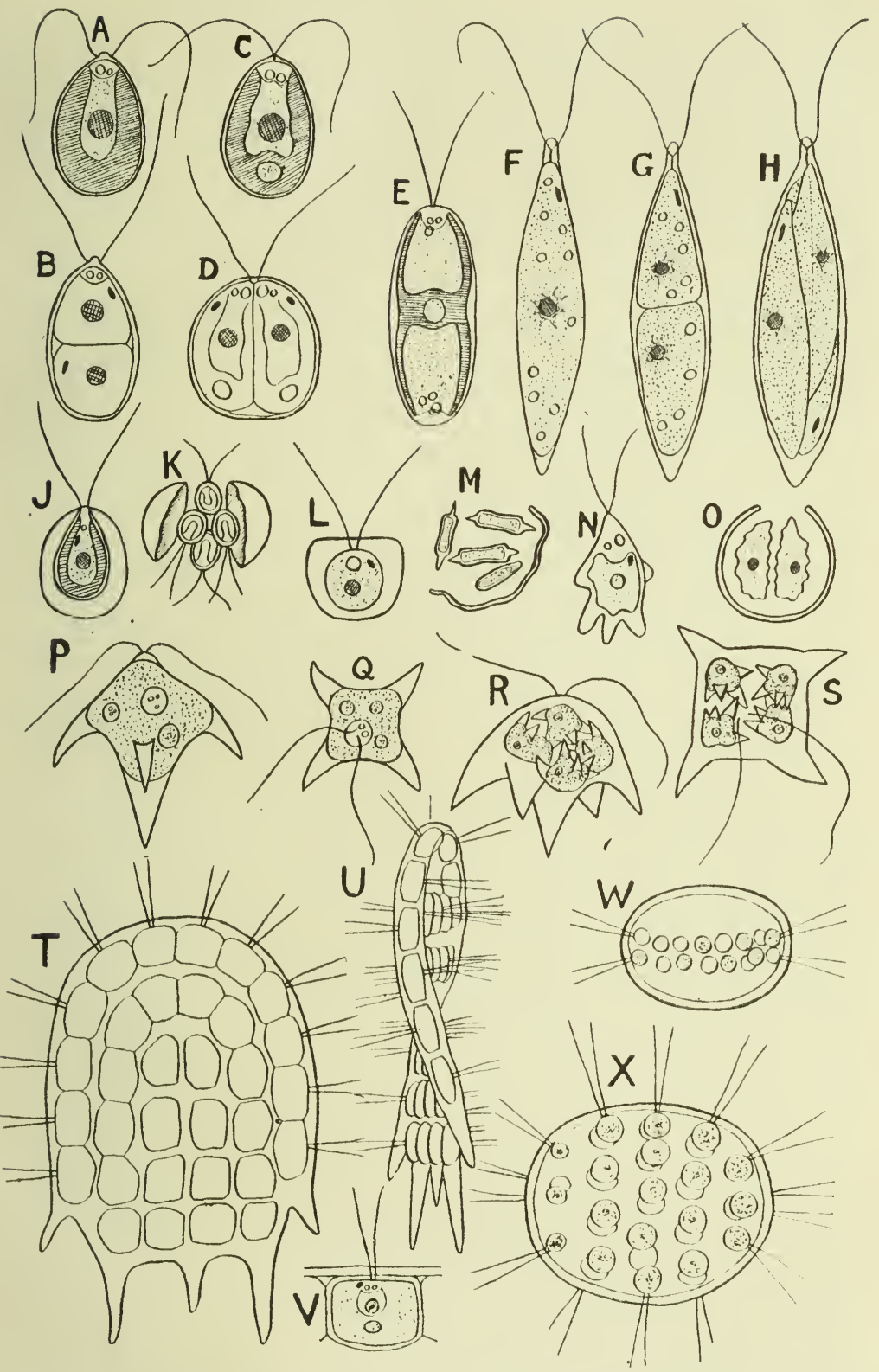

Fig. 4. Chlamydomonadace . A, B, Chlamydomonas (Chloromonas) variabilis Dang.: this species has no pyrenoid; $C$ shows transverse division. C, D, Chl. Ehvenbergii Gorosch. (longitudinal division shown in D). E, Agloë biciliata Pascher. F, G, H, Chlorogonium euchlorum Ehrb: in $G$ the protoplast shows transverse division into two, in $\mathrm{H}$ the four daughter-cells formed by a further division have become arranged longitudinally within the mother-cell. $\mathrm{J}, \mathrm{K}$, Coccomonas orbicularis Stein : in $\mathrm{K}$ the wall of the resting cell has ruptured to sct free the four daughter-cells. L, M, Pteromonas alata (Cohn) Seligo: 
in $\mathrm{XI}$ the liberation of the four daughter-cells. $\mathrm{N}, \mathrm{O}$, Lobomouas Francei Dang. $\mathrm{P}$ to $\mathrm{S}$. Brachiomonas submarina Bohlin: $\mathrm{P}$ and $\mathrm{R}$ in side view, $\mathrm{Q}$ and $\mathrm{S}$ in anterior view; in $\mathrm{R}$ and $\mathrm{S}$ the formation of daughter cells. $\mathrm{T}$ to $\mathrm{V}$, Platydorina caudata Kofoid: T, surface view ; U, side view, showing the slight spiral twisting of the plate-lilie conobium; V, a single cell. IV, Stephanoon Askenasii Schewl. $\mathrm{X}$, Pleodorina illinoisensis Kofoid (the four small vegetative cells are shown at the left).

A to D, F to $\mathrm{H}$, from Jacobsen ; E, from Pascher ; J, K, from Stein ; L, I, from IVille; N, O. from Dangeard: P, Q, R, S, from West; T, U, V, X, from Kofoid; IV, from Schewialkoff.

Fritsch (46) this recalls the autospore formation characteristic of the Scenedesmaceæ and Phytheliaceæ among the Protococcales. Included in the unicellular Chlamydomonadacez are two colourless saprophytic forms-Polytoma (Francé, 43; Prowazel, 117) which is probably derived from Chlamydomonas, and Chlamydoblepharis which resembles Coccomonas. In his recent classification of the Volvocales, Wille (150) includes in the Chlamydomonadacer the genera Nephroselmis and Glaococcus, but the former is better placed among the Cryptomonads, while the latter belongs to Tetrasporaceæ. Of the six genera appended by IVille to the Volvocales as doubtful forms, Gloomonas may be placed near Chloromonas, despite its possession of numerous chloroplasts; Cylindromonas and Mesostigmu probably belong to Euglenineæ, and Tetratomu to Carteriaceæ; Xanthodiscus and Kleiniella are still imperfectly known, though Lemmermann (85) places the former in the Cryptomonadinex, while Francé (43) regards Kleiniella as allied to Coccomonas and Chlanydoblepharis.

As pointed out by Fritsch (46), of the three attempts at cœnobium formation seen in the Volvocales, that represented by Gonium has alone proved successful and lias given rise to the remarlably complete ascending series which culminates in Volvox. Schussnig (133) has recently described in detail the lite history of Gonium pectorale, and has shown that in addition to the formation of daughter colonies and zoogonidia, reproduction occurs by means of aplanospores and by the conjugation of isogamous zoogametes; while Harper (54) has carefully studied the structure and division of the Gonium colony. Pringsheim's observation that Pandorina shows heterogamy does not appear to have been repeated by recent writers on the life history of this genus; while no further observations on the peculiar genus Platydorina (Fig. 4, T to V) have apparently been made since its discovery by Kofoid (70) and its life history is still unknown. Schewiakoff's genera Mastigosphara and Stephanoon (126) appear to bridge the gap between Pandorina and Eudorina, though their life history is unknown. In Mastigosphara, the cells, which have but one flagellum, are less closely packed in the spherical cœenobium than is the case in Pandorina; while in Stephanoon (Fig. 4, IV) the cells are arranged on the equator of the conobium, as in Stephanosphara, but in two alternating rows. In Eudorina the cells are spaced out at the periphery of the spherical cœnobium, though showing a tendency to be arranged in circles, but all the cells are alike capable of reproduction, whereas in Pleodorina and Volvox there is differentiation into vegetative and reproductive cells. Until recently, Pleodorina with two species- $P$. californica Shaw (138), P. illinoisensis Kofoid (69)_was known only from the United 
States, but $P$. californica has since been discovered in Ceylon (Fritsch, 47), in France (Chatton, 23), and in Java (Woloszynska, 154), while $P$. illinoisensis has been found near Heidelberg (Merton, 92), and the life history of this genus has been worled out in detail by Chatton and by Merton. In P. illinoisensis (Fig. 4, X) the cœnobium consists of 32 (more rarely 16 or 64 ) cells, arranged in five circles, the two polar circles having four cells each and the other three circles eight cells each; the cells of the anterior polar quartette are vegetative only, never dividing to form new cœnobia and are smaller than the remaining cells. This species thus forms a transition from Eudorina to Pleodorina califormica, in which the cœnobium consists of 64 or 128 cells and is sharply divided into an anterior hemisphere in which the cells are purely vegetative and only one-third to one-half as large as the reproductive cells of the posterior hemisphere. In Pleodorina the cells have two contractile vacuoles and numerous pyrenoids, and

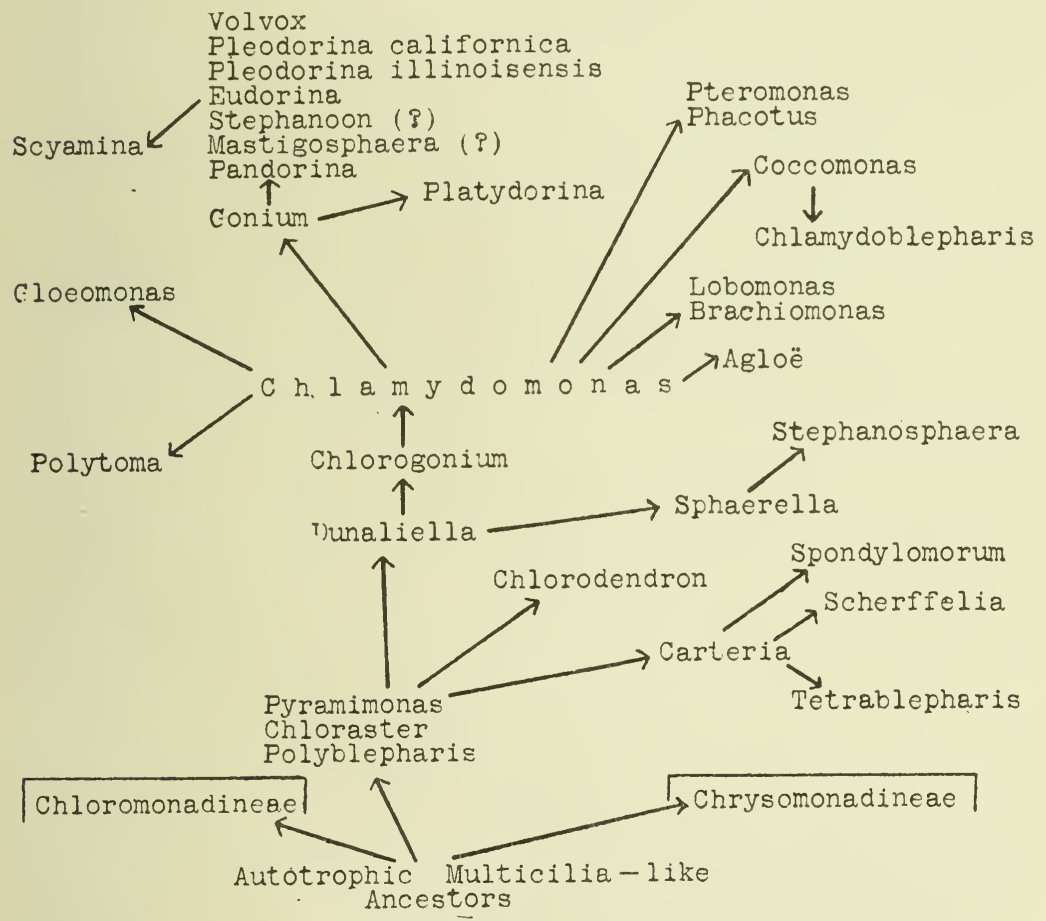

Table B.-Suggested Phylogeny of the Volvocales. For details, see Text.

the chloroplast is reticulate; in both species, oogamous sexual reproduction occurs as in Eudorina, any of the potentially reproductive cells producing either a mass of antherozoids, an oosphere, or a daughter-cœnobium. The two species of Pleodorina form perfect connecting links between Eudorina and Volvox, in which last genus the vast majority of the cells in the large conobium are vegetative and there is still more pronounced differentiation between 
the vegetative and the reproductive cells and more marked oogamy, the oogonial cells being differentiated at an early stage in the formation of the cœnobium and having no flagella. Van Tieghen's genus Scyamina is an imperfectly known colourless form, in which the numerous cells are placed at different depths in the spherical cœnobium, instead of being confined to the periphery as in Eudorina; it is quite uncertain whether it represents a saprophytic offshoot from a Eudorina-like type, or a form derived from Polytonn by cœnobial development, or indeed whether it is rightly placed in the Volvocales at all.

The inter-relationships of the Volvocales, as here suggested, are indicated on the accompanying Table B.

\section{VI.-The Chrysomonads.}

Since the publication of Senn's compilation in 1900, much work has been done on the Flagellate forms included by him in the Chrysomonadineæ and Cryptomonadineæ. From the extensive recent literature of these forms, to which Pascher has been the largest contributor, it will suffice to select for mention sertain results which are of special interest in connexion with the phylogeny of the Algæ. Various new genera have been added to those enumerated by Senn, and some modifications of the earlier classification have been suggested. Senn divides the Chrysomonadinere into three families characterised respectively by the possession of a single flagellum (Chromulinaceæ), two equal flagella (Hymenomondaceæ), and two unequal flagella (Ochromonadaceæ). Scherffel (125) has shown that Monas, Oikomonas, and various other genera placed by Senn in the Protomastigineæ are better regarded as colourless forms derived Chrysomonads; for instance, they show precise agreement with normal coloured Chrysomonads in producing leucosin, in the mode of encystment, and in various cytological details. In describing a new species of Gymnodinium, a genus belonging to the simpler Peridiniales which have been regarded as derived from the Chrysomonadineæ (see below), Ohno (94) criticises the systematic value of the flagellum number in the classification of the Flagellata. This new species differs from all other Peridiniales in having two longitudinal flagella instead of one, in addition to the usual transverse flagellum, but otherwise must be placed in the genus Gymnodinium. The same objection has been raised with regard to the lower Green Algæ, ${ }^{1}$ but Senn's classification is accepted by Pascher and other recent writers on the Chrysomonads, since (as in the case of the Green Algæ) the groups are distinguished by characters other than the number of flagella. In Pascher's suggested classification (101), the Cryptomonads are merged in the Chrysomonadineæ, which are divided into four orders. The first three of these (Chromulinales, Isochrysidales, Ochromonadales) coincide with Senn's three families of Chrysomonadineæ, while the fourth (Phæochrysidales) is characterised by the possession of laterally inserted flagella-in the other three orders the flagella are terminal-and includes the Cryptomonadineæ of Senn.

'See Review of Wille's classification of Green Algæ, by R.P.G., NEw Phytologist, vol. IX., 1910, p. 78. 
The Chrysomonads are characterised by a peculiar endogenous method of cyst formation. Before a definite cyst appears, there is visible within the protoplast a membrane covered by an amoboid protoplasmic layer (Fig. 5, 11-14), which produces sculpturing on the outer surface of the cyst membrane, but later this protoplasm retreats within the membrane through a pore which has been left, this pore being afterwards closed by a plug which in some cases consists of cellulose; the membrane usually contains silica. A similar method of cyst formation occurs in certain colourless heterotrophic genera which have hitherto been placed in the Protomastiginex, and on this ground, as well as on account of other cytological resemblances, it is suggested that these forms should be transferred to the Chrysumonads. These forms, which may be regarded as colourless derivatives from normal autotrophic Chrysomonads-corresponding with the colourless forms (Polytoma, etc.) included in the Volvocales-belong to the genera Monas, Oikomonas, Dendromonas, Antophysa, Cephalothammion, etc. It would appear that further investigations will lead to a considerable number of genera being transferred from the Protomastigineæ to the Chrysomonads, and doubtless to other groups of pigmented Flagellata, if we accept the view that where colourless and coloured Flagellates show close agreement in every character save the presence or absence of assimilatory pigments, the colourless forms are to be regarded as having arisen from the coloured as an adaptation to a heterotrophic mode of nutrition.

The recent work of Pascher, Scherffel, Senn, and others has shown that the Chrysomonadiner (in the wider sense, as defined by Pascher) form a remarkably diversified group, in each order of which various parallel developments may be traced, starting from relatively simple free-living and usually small forms. The chief of these parallel developments are the formation of motile colonies analogous with those of the higher Volvocales, and of variously constructed non-motile colonies corresponding with those of the Tetrasporacex and other families of Protococcales characterised by aggregation of the cells into mucilaginous masses; the occurrence of amœboid forms and of amœboid phases, the latter perhaps to be regarded as reversions to an ancestral condition; the lobing, division and further elaboration of the primitively indefinite and reticulate or basin-shaped chromatophore; the coördination of the contractile vacuoles to form a pulsating vacuole system similar to that seen in the Chloromonadiner and Eugleniner; the substitution of solid carbohydrate assimilates (paramylum and starch) for oil and leucosin; the elaboration of the outer protoplasmic layer into a firm periplast and finally into a definite membrane (in some cases consisting of cellulose) which may form either a close-fitting or an outstanding and cup-like perisarc; the outgrowth of tentacles from the periplast; and the development of sculpturings and of various excrescences (ridges, spines, etc.) on the cell-wall.

The Chromulinales include the simplest forms of the Chrysomonadinex. In the lowest family, Chrysapsidaceæ, the cells are free-living and are amoboid; in Chrysapsis the chromatophore is an indefinite reticulate peripheral sheet, while in Chrysamaba and Nannochrysis it is basin-shaped, though in some species of Chrys. 
amcba it becomes deeply bilobed and even divided into two (Fig.5, 1,2). In Chrysapsis, division often occurs within a gelatinous investment, while in Nannochrysis the formation of a palmella-stage is more pronounced and several divisions occur before the products of division become free by dissolution of the jelly. These simple forms show marked resemblance to some of the simpler Protomastiginex; Chrysamoba is very similar to Mastigamoba and Oikomonas, apart from the absence of a chromatophore in the latter genera.

The Chromulinacex, forming the largest family of Chromulinales, include solitary and colonial forms, the former showing a elaboration of the protoplast as compared with the Chrysapsidacer; there is usually a single basin-shaped chromatophore, but sometimes two or even more may be present. Among the solitary forms, Chrysococcus (Fig. 5, 15, 18) has a thick shell or perisarc closely investing the periplast, but with a small anterior opening for the flagellum, the periplast of some species is ornamented with wart-like out-growths, and there is either a basin-shaped chromatophore or two lateral curved plate-like chromatophores, or several discoid chromatophores (Pascher, 99). A further elaboration is seen in the curious epiphytic genera Chrysopyxis and Stylococcus, in which the body is amoboid and lies loosely within a goblet-like shell or perisarc which projects freely beyond it, and is produced at the base into a hapteron; longitudinal division occurs within the shell, and one of the daughter-cells escapes, produces a perisarc with an attaching process, and settles down; the cell contains cellulose, and the "flagellum" is in reality a "rhizopodium," or branched filamentous pseudopodium, at any rate in Chryopyxis (Fig. 5, 26-30), which may be regarded as practically a Chrysamoba that has become epiphytic and produced a shell; in Stylococcus (Fig. 5, 23-25), the "flagellum" is unbranched, but differs from the normal type of flagellum in being motionless and is doubtless pseudopodial.

The colonial genera of Chromulinaceæ show an advance upon the Chrysapsidaceæ, in that the palmella stage is more enduring, and in the genus Hydrurus becomes dominant. In Chromulina Hokeana, division occurs in the motile state, and the products of two or three successive divisions remain coherent to form a four- or eight-celled motile colony, comparable with the cœnobia of Gonium and Pandorina, and thus representing the "Volvocine tendency" which has appeared independently in several distinct groups of Chrysomonads. In most species of Chromulina (Fig. 5, 9-14). however, division occurs in a resting palmella state (after the cells have lost their flagellum), giving rise to an indefinite mucilaginous mass; the free flagellate cells are amoboid and resemble Chry'samoba. A far more enduring and definite palmella state occurs in Hydrurus (Fig. 5, 37-41); the motile cells ("zoogonidia") are of tetrahedral form, with the flagellum at the broader anterior end and on coming to rest lose the flagellum, become attached assume an ellipsoid form, secrete a mucilaginous stalk, and by repeated division give rise to an elaborately and regularly brancbed colony of considerable size. In this colony the cells are more crowded in the smaller branches than in the main axis and the larger branches; the whole structure hehaves like a multicellular plant, grorvth in length deperds on single apical cells, and the zoogonidia are produced from the branches, two or four arising by division of a parent-cell. 


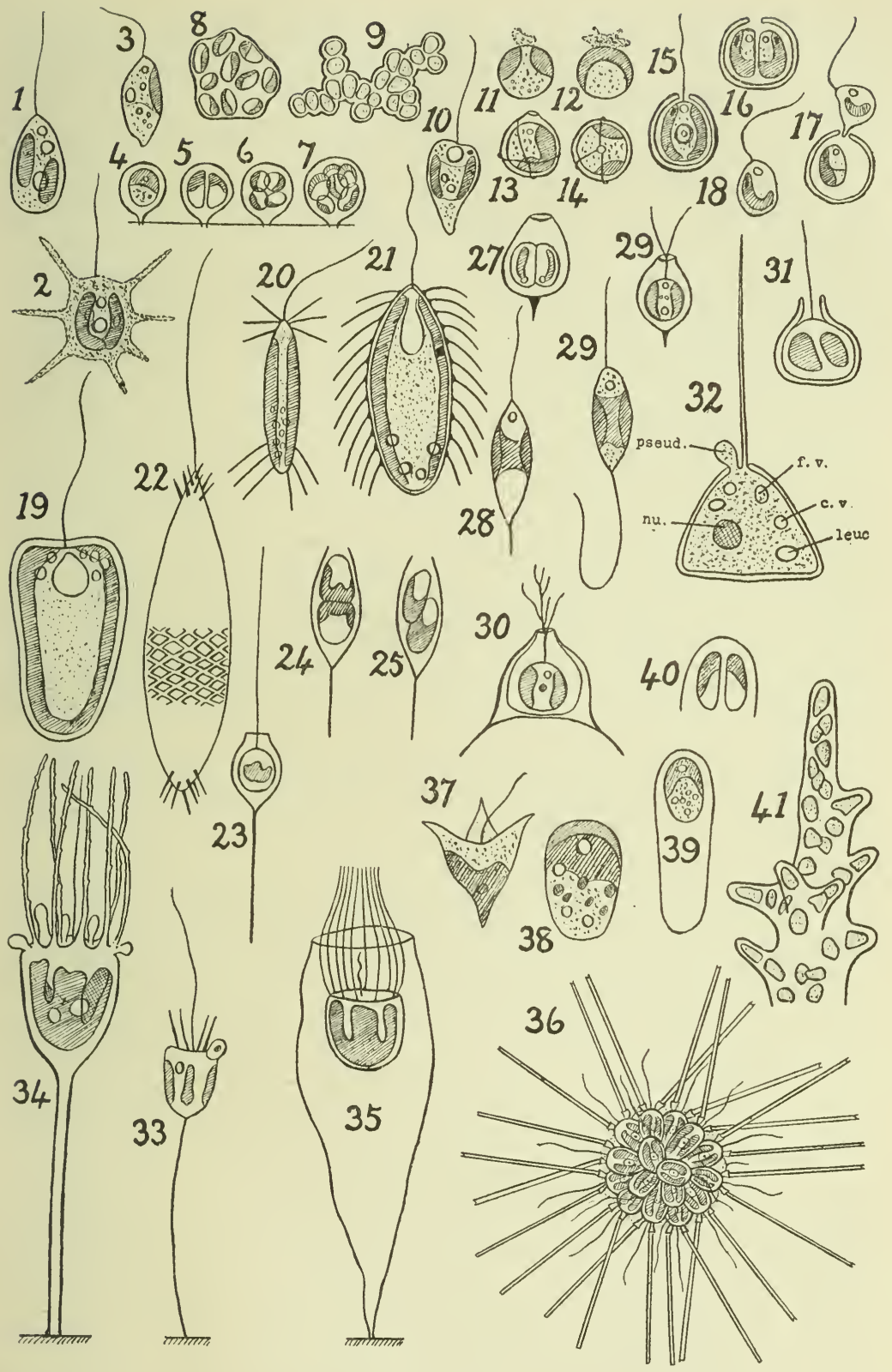

Fig. 5. Chromulinales. -1 and 2 , Chrysamceba radians Klebs: 1 , a normal free swimming individual; 2 , an amœboid form. 3 to 9, Chromulina Rosanoffii (Woronin) Bütschli : 3, motile cell or zoogonidium ; 4 to 7 , division of a motionless encysted cell floating on the surface of the water; 8 and 9 , formation of palmella stage. 10, Chromulina ovalis Klebs, motile cell. 11 to 14 . C'hromulina nebulosa Cienk.. showing development of cyst: in 11 and 12, a portion 
of the protoplasm is extruded from a pore, this amœboid mass being used up in the formation of the cyst membrane; 13 and 14 are different views of the fully formed cyst. 15 to 18 , Chrysococcus rufescens Klebs : 15, a motile cell, in optical section, showing projection of the flagellum through a pore in the thick perisarc; 16, division of the protoplast; 17, escape of a daughter-cell; 18, free daughter-cell, before formation of perisarc. 19, Microglena punctifera Ehrb., showing the vacuole system. 20, Mallomonas litomesa Stokes, with flinty processes at anterior and posterior ends of the cell, 21, Mallomonas acaroides Ehrb., with similar processes nearly covering the cell. 22, Mallomonas pulcherrima Stokes, showing in part the reticulate sculpture of the perisarc. 23 to 25 , Stylococcus aureus Chodat: two stages of division in 24 and 25. 26 to 30, Chrysopyxis bipes Stein : in 26 the flagellum is forked; 27 shows longitudinal division into two daughter-cells; 28 and 29, a daughter. cell with elongating posterior process for attachment-in 30 this process has wound around a Zygnema filament, part of which is seen in transverse section at the base of the sessile flask-like perisarc. 31, Lagynion Scherffeli Pascher. 32 , Heterolagynion Oedogonii Pascher : to the left of the stout motionless flagellum is a short blunt pseudopodium (pseud.); within the stout perisarc the protoplasm contains a nucleus ( $m u$.), a food vacuole (f.v.), two contractile vacuoles (c.v.), and two leucosin masses (leuc.) 33, Pedinella hexacostata Wys., with four stiff bristles at the base of the flagellum; on the right is an amœboid pseudopodium containing a food vacuole. 34, Cyrtophora pedicellatı Pascher, showing the central flagellum, the stout nodulose tentacles, and several pseudopodial processes at the anterior end of the protoplast. 35, Palatinella cyrtophora Laut., with short flagellum in the centre of the ring of tentacles. 36, Chrysospharella longispina Laut., a motile cœnobium of Chromulina-likc cells, each with two long flinty processes exserted from cup-like outgrowths of the periplast. 37 to 41 , Hydrurus fatidus (Vauch.) Kirchner: 37 , a motile cell or zoogonidium ; 38, motionless cell, which becomes attached by a gelatinous stalk (39) and by division (39) gives rise to the branching colony, a portion of which is shown in 41.

$1,2,10,15$ to $19,21,37$ to 40 , from Klebs; 3 to 9 , from Woronin ; 11 to 14, from Cienkowsky; 20, 22, from Stolks ; 23 to 25, from Chodat ; 26 to 30 , from Stein; 31, 32, 31, from Pascher; 33, from Wysotzki; 35, 36, from Lauterborn; 41, from Berthold.

Hydrurus and other palmelloid Chrysomonads have been regarded by some writers as belonging to the Phæophyaceæ, on account of the dominance of the palmella stage in the life history, but apart from the fact that various degrees of elaboration of this stage have been observed in undoubted Flagellates, the terminal insertion of the flagella in the lower Chrysomonads, as compared with the characteristic lateral flagella of the Brown Algæ, seems to form an insuperable obstacle to the derivation of the Phæophycere from these Chrysomonads. Despite the dominance and elaboration of its palmella stage, Hydrurus can hardly be said to have crossed the "border-line" between Flagellates and Algæ; it is simply a Flagellate, allied closely to the lower Chrysomonads, and represents the culmination of a line of palmelloid forms arising from types like Chrysapsis and Namnochrysis. The "Volvocine tendency" shown in Chromulina Hokeana is carried further in Chry'sostephanosphara, recently discovered by Scherffel; here the cœnobium consists of sixteen cells arranged as in Stephanosphara on the equator of a globular gelatinous mass, but later a palmelloid state is produced in which each cell has its own mucilaginous envelope.

Further elaboration in the external and internal characters of the cell is seen in the small family of Mallomonadacex, consisting of the two free-living genera Mallomonas and Microglena and the colonial genus Chrysospharella. In Mallomonas (Fig. 5, 20-22) the 
ovoid or elongated cell has a close-fitting shell composed of tesselated polygonal plates, and either each plate, or only those at the two ends of the body, may bear fine silicified outgrowths; there are two chromatophores, and the hinder end of the cell contains numerous contractile vacuoles, while at the anterior end there is a large noncontractile vacuole; the cysts are also covered with a silicified shell. In Microglena (Fig. 5, 19) the vacuole system is further elaborated, all the vacuoles being anterior, the smaller contractile vacuoles surrounding a large non-contractile vacuole; there is frequently a single basin-like chromatophore; the shell is thin and bears only scattered granular outgrowths. In Chrysospharella (Fig. 5, 36) the cells are united by their hinder ends in a spherical jelly, forming a motile Pandorina-like conobium; each cell bears on its free outer (anterior) end two small cup-like outgrowths from the shell (which has the same structure as in Mallomonas) and from each of these cups there springs a long flinty spicule; the internal structure of the cells resembles that of Microglena, there are two chromatophores, each with a stigma.

Pascher (102) has founded a fourth family of Chromulinales, the Cyrtophoraceæ, upon three very remarkable epiphytic genera which have probably arisen from a type like Chrysopyxis. These genera-Pedinella, Palatinella, Cyrtophora (Fig. 5, 33-35)-are either sessile or stalked, the body is flattened anteriorly and bears a central flagellum surrounded by from six to twenty pseudopodia; there is a single basin-shaped chromatophore, but this is more or less deeply lobed in front. Pascher (109) has recently described a genus (Lagynion) which forms a transition between Chrysopyxis and the Crytophoracer; in Lagynion (Fig. 5, 31) the cell is fixed by a broad base, and within the collar-like projecting portion of the shell the protoplast protrudes short amœboid pseudopodia around the base of the long motionless flagellum or "rhizopodium." The same writer describes a colourless genus, Heterolagy'nion (Fig. 5, 32,) evidently derived from Lagynion, and points out that the Cyrtophoraceæ show a remarkable parallelism with the Pantostomatinean genera Pteridomonas and Actinomonas.

In the Isochrysidales the cells are either free-living or united to form colonies of the Volvocine type. Of the nine genera placed here (as Hymenomonadaceæ) by Senn, the unicellular genus Wysotzkia sliould be transferred to the Phæochrysidales (Cryptomonads), and the palmelloid genera Phaocy'stis (Ostenfeld, 96), and Nageliella (Correns, 27) to the Phæocapsaceæ; in these three genera the two flagella are inserted laterally, and while $W y$ sotzkia is clearly related to the simpler Cryptomonads, especially to the tivo recently discovered genera Protochrysis and Cryptochrysis, it seems equally obvious that the affinities of Phaocystis and Nageliella are with the lower Phæopinycex, hence they should be removed from the Brown Flagellata altogether. In the simplest Isochrysid genus, Hymenomonas (Fig. 6, 1), the cell has a firm thick periplast, though the anterior portion of the protoplast is naked and capable of putting forth pseudopodia. In this order, evolution appears to have taken place in two directions, one leading to epiphytic forms recalling Chrysopyxis and its allies among the Chromulinales, the other to motile colonies. Of the epiphytic forms, Stylochrysalis (Fig. 6, 3), 
is attached to its substratum (usually an Eudorina colony), by a long stalk dilated at the base, and has a thin periplast; while Derepyxis (Fig. 6,2) resembles Chrysopyxis in having an outstanding perisarc with a projecting collar. Of the colonial forms, Syncrypta and Synura have globose motile coenobia, consisting of 16 to 64

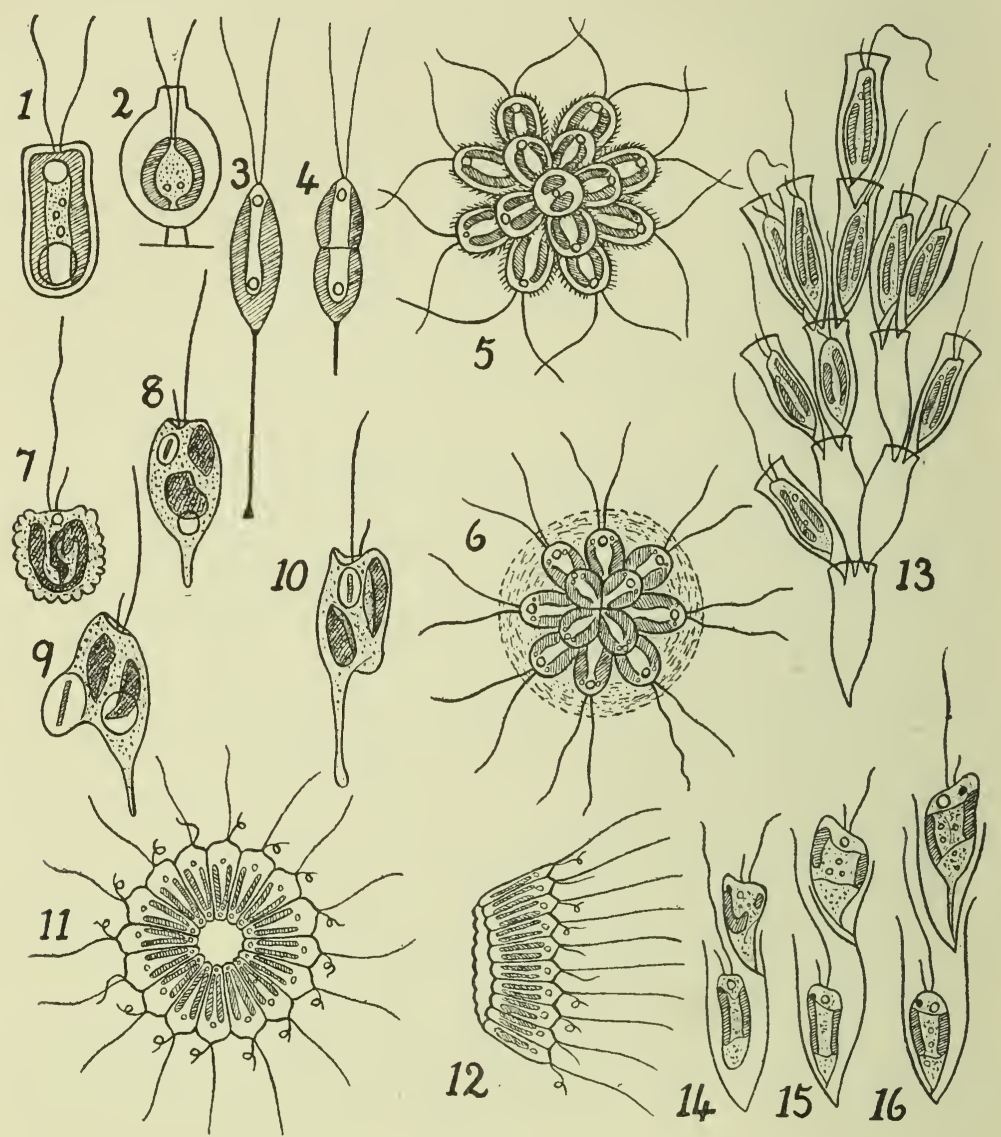

Fig. 6. Isochrysidales ( 1 to 6 ) and Ochromonadales ( 7 to 16$).-1$, Hymenomonas roseola Stein. 2, Derepyxis dispar Stokes. 3, Stylochrysalis parasitica Stein (in 4, transverse division is shown). 5, Synura Uvella Erhb. 6, Syncrypta Volvox Erhb. 7, Ochromonas crenata Klebs. 8 to 10. Ochromonas mutabilis Klebs, showing migration of food vacuoles within the protoplasm and amoboid changes of form of the cell. 11, 12, Cyclonexis annularis Stokes : in 11 the cœnobium is seen from the surface, in 12 from the side. 13 to 16, Dinobryon Sertularia Ehrb.: in 14 to 16 , stages in division and perisarc formation.

1, from Klebs; 2, 11, 12, from Stokes; 3 to 6, from Stein; 7 to 10,14 to 16, from Klebs; 13 , from Senn.

biflagellate individuals closely aggregated in a radial manner, their pointed hinder ends directed towards the centre of the cœnobium; in Syncrypta (Fig. 6, 6) the cells have a thin periplast and the 
colony is invested in mucilage through which the flagella protrude, in Synura (Fig. 6, 5) there is no mucilaginous covering and each cell of the colony has a firm periplast beset with spines or warty outgrowths-in S. Klebsianc each cell bears two flinty spicules, as in Chrysospharella. Pascher (110) has observed that in Synura uvella the contents of a cell may escape as an amoba instead of a flagellate swarmer, and that the latter may also become amoboid after liberation, and that from both flagellate and amoboid forms palmella-states may arise by division in a mucilaginous motionless condition (Con rad, 26).

The Ochromonadales, though a smaller order than the Chromulinales and Isochrysidales, shows parallel developments of the same kind. Here again we begin with a unicellular and potentially amoboid type, Ociromonas (Fig. 6, 7-10), which, except in having two unequal flagella, closely resembles Chrysamoeba among the Chromulinales; most of the species are free-swimming, but $O$. tenera becomes fixed by its hinder end; the thin periplast is capable of secret!ng mucilage, and in $O$. socia division occur's in the motile phase and gives rise to small, generally four-celled, motile cœnobia; usually, division occurs in a resting state, and in $O$. botrys a large mass of cells enveloped in mucilage may be formed in this way. In Cyclonexis (Fig. 6,11,12), the individual cells are like those of Ochromonas, but they remain in lateral contact in such a manner as to form a radiating ring-like cœenobium, consisting usually of 16 cells. In Uroglena a curious type of cœenobium is formed as the result of repeated division of the stalked cells and the formation of a spherical mucilage mass in which the cells lie near the periphery while the branching stalks radiate from the centre. In Dinobryon (Fig. 6, 13-16) the cell is spindle-shaped and is invested loosely by a vase-like shell widely open above; when division occurs, the daughter cells may either escape or (in most species) become attached to the mouth of the shell and produce a shell of their own ; by repetition of this process, a branching colony is built up; the shell in some cases gives cellulose reactions. The genus Dinobryon has been monographed by Brunnthaler (16) and by Lemmermann (79).

\section{ViI.-The Cryptononads and their Relationships.}

$\mathrm{T}^{\mathrm{T}}$ would appear that the three orders of Chrysomonadinex 1 dealt with thus far (Chromulinales, Isochrysidales, Ochromonadales) have not given rise to anything higher than a Flagellate, though they show various attempts at the formation of colonies -in all three orders we find gradual elaboration of motile "Volvocine" cœenobia, and also the working out of a palmelloid or "Tetrasporine" tendency towards the formation and dominance of a non-motile multicellular vegetative condition. It may be noted that "Volvocine" cœnobia occur also among the Protomastiginere (Protospongia, Spharceca, etc.), in addition to the dendroid colonies of the Dinobryon type (Codonocladium, Salpingoeca, etc.) derived from solitary "choanflagellate" forms (i.e., forms with outstanding collar-bearing perisarc). Whether the remarkable resemblances between the "mastigamoboid," the "Volvo- 
cine," and the solitary and dendroid "choanoflagellate" types met with in the colourless Pantostomatineæ and Protomastiginere on one hand and the Chrysomonadinere on the other are to be interpreted as examples of parallel developments, or whether, as suggested by Pascher and Scherffel, they indicate derivation of part at any rate of the colourless Flagellate families from Chrysomonads, the trend of recent work on the Brown Flagellata is decidedly against the view that the Chrysomonads comprised in families Chromulinales, Isochrysidales, and Ochromonadales have given rise to the Brown Algre.

The case appears to be quite different with the fourth Chrysomonad order, the Phreochrysidales or Cryptomonads, which are distinguished by the lateral insertion of the two flagella. The simplest forms are Pascher's new genera C'ryptochrysis and Protochrysis (103); Wysotzkia (hitherto placed in the Isochrysidales); and Nephroselmis (Senn, 136), which IVille (150) includes in the Volvocaceæ. Senn (135) defines the Cryptomonads as having an ovoid and flattened body, with two equal flagella arising just behind the anterior end from a groove which is continued into a gullet-like cavity, and having one or two contractile vacuoles which are not coördinated into a pulsating system. According to Senn they are also further differentiated from the Chrysomonads by producing starch, or, at any rate, a refractive solid carbohydrate. The researches of Pascher and others have shown, however, that the Cryptomonads, though a highly specialised group, cannot be set apart from the Chrysomonads, as a separate group of the Flagellata, and that they have arisen from the Chrysomonads by further internal differention of the protoplast, accompanied by a shifting of the flagella from a terminal to a lateral position. In Wysotzkia (Fig. $7,3,4)$, the posterior end of the protoplast, behind the two chromatophores, is naked and capable of amœboid movement. In Cryptochrysis (Fig. 7, 2), the lateral insertion of the flagella is more marked than in Wysotzkia, the flagella arising from a deep longitudinal groove which is about half the length of the body and is covered with minute granules; nutrition is purely holophytic and the assimilate consists of disc-like grains giving a reddish violet colour with iodine; division takes place in the motile state, and is longitudinal.

Cryptochrysis appears to be the most primitive Cryptomonad at present known; Wysotzkia, though simpler in some respects, undergoes transverse division, and is adapted for partial or facultative holozoic nutrition. Nephroselmis and Protochrysis differ from these genera, and indeed from the remaining Cryptomonads, in that the groove is transverse and occupies the middle of the protoplast, so that the flagella arise from the middle of the concave side of the body; in Nephroselmis there is a single chromatophore which follows the outline of the body and is interrupted only at the point of emergence of the flagella, and division occurs in the motile condition, whereas in Protochrysis (Fig. 7, 1), there are two chromatophores, and division occurs after the cells have become rounded off and invested in mucilage, a four- or eightcelled colony being formed by repeated division in this palmellastate. In Cryptomonas (Fig. 7, 5-7), the groove found in the 
genera just mentioned is replaced by a canal which leads into the interior of the protoplast; in some species this canal is quite short, in others it extends for about half the length of the body. In most species of Cryptomonas the assimilate is like that found in Crypto-

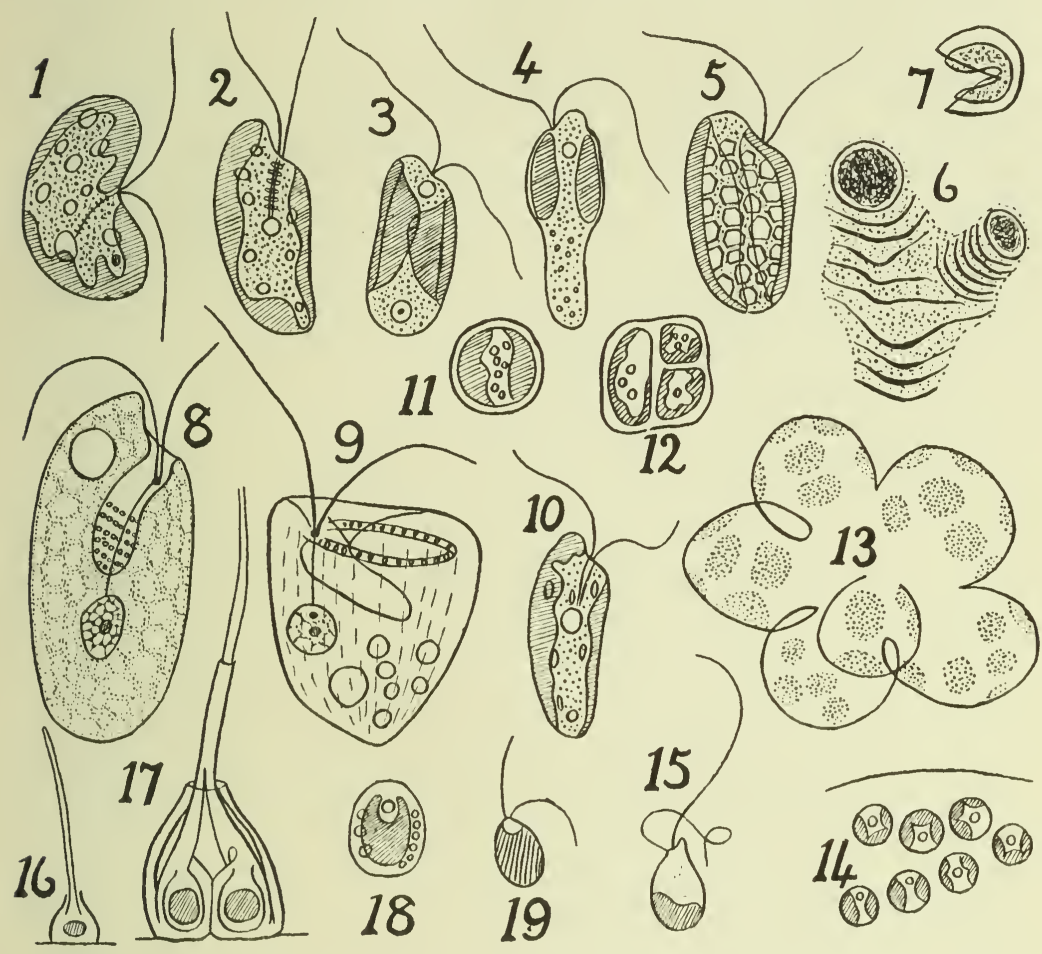

Fig. 7. Cryptomonads (1 to 9) and Phæocapsacez (10 to 19) :1, Protochrysis phaophyceanum Pascher. 2, Cryptochrysis commutata Pascher. 3, 4, Wysotzkia biciliata (IVys.) Lemmerm. : 3, ordinary form ; 4, metabolic (amœboid) form, showing protrusion of pseudopodia anteriorly and posteriorly. 5 to 7 , Cryptomonas erosa Ehrb. : 5 , ordinary motile cell; 6 , two encysted cells with gelatinous envelopes; 7, ruptured cyst membrane. 8, Chilomonas Paramacium Ehrb.: the flagella arise on the ventral side of the "gullet" (which shows several circles of granular markings in its lower half), from a small body which is connected with the nucleus by means of a long fibril. 9, Cyathomonas truncata (From.) Fresen. : structure essentially as in Chilomonas; there are numerous food vactioles at the base of the cell, the single contractile vacuole is seen near the opening of the "gullet." 10 to 12, Phrooplax marina (Reinisch) Pascher: 10, motile cell ; 11 and 12, young colonies (beginning of palmella stage, which when fully developed resembles that seen in Chromulina Rosanoffi, Fig. 5, 9). 13 to 15, Phroocystis Poucheti Lagerh. : 13, gelatious colony (palmella state); 14, a portion of same, more highly magnified) ; 15, a motile cell (zoogonidium). 16 to 19, Nageliella flagellifera Correns : 11 and 12, one-celled and three-celled stages in development of colony, showing the perisarc and bristles; 18, a single cell, showing the bell-shaped chromatophores; 19 a motile cell (zoogonidium).

1, 2, from Pascher; 3, 4, from Wysotzki ; 5 to 7, from Senn ; 8, 9, from Ulehla (with some details inserted from Hartmann and Chagos); 10 to 12 , from Reinisch ; 13, 14, from Lagerheim ; 15, from Pouchet; 16 to 19, from Correns. 
chrysis, but in $C$. ovata starch is produced; longitudinal division may occur in either the motile or the encysted condition, and the cyst membrane gives the reactions of the cellulose. Chroomonas and Cyanomonas resemble Cryptomonas, but the chromatophores are blue-green, while Rhodomonas is allied to these forms but has a red chromatophore. Chilomonas (Fig. 7,8 ) also resembles Crypto. monas in structure, but is saprophytic, though it produces starch; Botryomonas (Schmidle, 131) is another saprophytic starch-producing form, in which the cells become aggregated to build up a branched gelatinous colony, and the periplast gives cellulose reactions. Cythomonas (Ulehla, 143) and Oxyrrhis (Senn, 136), though placed by Senn in the Protomastiginer, are apparently related closely to Cryptomonas through Chilomonas, and may be regarded as colourless forms derived from a Cryptomonas-like type; in Cyathomonas (Fig. 7,9) nutrition is mainly saprophytic, but solid food can also be ingested at the anterior end of the body, while in Oxyrrhis nutrition is mainly holozoic and this genus differs from its allies in undergoing transverse division.

The Cryptomonads have probably arisen from simple Chryso. monads, with two flagella either of unequal length or with different orientation (one directed forwards and the other backwards in swimming). Such a form as Ochromonas, for instance, may well have given rise to the Chloromonadinere on one hand and to the Cryptomonads on the other, for these two groups show somewhat striking parallelisms, such as the organisation of the vacuole system into small actively contractile vacuoles which open into a large anterior non-contractile vacuole or into a groove or canal. The Chloromonads have probably given rise on one hand to the highly differentiated Euglenineæ which have no Algal affinities, and on the other to the Algal group "Confervales" (Heterokontæ). Similarly the simpler Cryptomonads-e.g., Cryptochry'sis and Protochrysis-appear to have given rise on one hand to highly organised Flagellates like Cryptomonas, Chilomonas, Cyathomonas, and Oxyrrhis-corresponding to the Euglenineæ in the green series-and on the other to the Phæocapsaceæ, which form the starting-point of the Brown Algæ.

The Phæocapsaceæ, corresponding roughly with the Tetrasporaceæ and Palmellaceæ in the green series, are apparently a somewhat heterogenous group, marked by the dominance of the non-motile phase. One of the simplest genera is Phaocystis (Fig. $7,13-15$ ) in which the cells have from one to four plate-like chromatophores and are aggregated to form a rounded gelatinous colony, the motionless cells being rounded, while the motile cells ("zoogonidia") are biflagellate and have the same structure as Wysotzkia (Lagerheim, 73; Ostenfeld, 96; Scherffel, 122). In a similar form described by Reinisch (120) as Phaococcus marinus (Fig. 7, 10-12) but regarded by Pascher (104) as the type of a new genus, Phaoplax, the motile cells correspond closely to Cryptochrysis. Phaococcus Clementi is a gelatinous form adapted to subaërial life, the cells having firm envelopes, and the motile cells show typical Cryptomonad structure; whether $P$. paludosa described by West (146) belongs to this genus, or indeed to the Phrocapsacer, is somewhat doubtful, since in his figures the motile cells resemble those of the Isochrysidal Chrysomonads and not the Cryptomonads. 


\section{The Cryptomonads and their Relationships.}

The position of Phaosphara West is also doubtful, as the motile cells have apparently not yet been observed; the same is the case with Stichoglca and Gleothammion, which would be included in the Phrocapsaceæ if their motile cells were found to show Cryptomonad characters. Negeliella is epiphytic and forms multicellular discs, the individual cells producing a perisarc prolonged into a bristle; the motile cells have a single brown chromatophore and two laterally inserted fiagella. The genus Phaothammion appears to represent the highest form of the Phæocapsacer, while Pleurocladia leads directly to the Ectocarpacere and is placed in that group by Kjellman and Svedelius (66). A useful bibliography of the genus Phaothamion is given by M'Keever (91), who recently discovered $P$. confervicolum (the only species known) in Scotland-it was previously recorded only from Siveden, Germany and Italy. There appears to be some doubt as to the insertion of the flagella and the nature of the motile cells; according to Lagerheim the latter are zoogonidia with terminal flagella and no eye-spot, while Borzi described the conjugation of isogamous gametes with lateral flagella and a red stigma. Oltmanns (95) places Phoothammion, with the other genera here regarded as forming the family Phæocapsaceæ, among the Chrysomonadineæ. This genus is, however, apparently related very closely to Pleurocladia, which has the typical gonidangia and gametangia of the Ectocarpacex. Bohlin's genus Phaodactylon (9) cannot be included in the Phæo. capsaceæ, but is probably a Chrysomonad in which adaptation to plankton conditions has resulted in loss of the flagella; its curious three-armed cell recalls the tetrahedal motile cells of Hydrurus.

The greatest difficulty in the way of deriving the Phæophyceæ from the Brown Flagellates has been the characteristic lateral insertion of the flagella in the motile cells of the Brown Algæexcepting in the Dictyotacer, which are somewhat isolated among the Phæophyceaæ. This difficulty has, however, been overcome by the discovery of Protochrysis, in which the furrow from which the flagella arise, instead of being longitudinal and subapical as in other Cryptomonads, is transverse, so that the Hagella arise from the middle of the body, one flagellum being directed forwards and the other backwards. Protochrysis appears to stand very near the ancestral type which gave rise to the lower Phæophycer or to the series of transitional forms (Phæocapsaceæ) leading through Phaeothammion and Pleurocladia to the Ectocarpaceæ.

The work of Pascher and Scherffel supports Klebs' view that the Cryptomonads have arisen from the Chrysomonads and have no direct relationships with any other Flagellate group excepting possibly the Dinoflagellata (Peridiniales). Pascher, as we have already seen, merges the Cryptomonads in the order Chrysomonadiner, and has shown that the organisation of a pulsating vacuole system, previously regarded as found only in the Chloromonads and the Euglenineæ, occurs not only in the Cryptomonads but also among the Chrysomonad groups. Another distinction made by previous writers between the Cryptomonads and Chrysomonads has broken down, namely, that relating to the nature of the assimilation products. According to Senn, the Chrysomonads produce oil and leucosin, and nutrition may be holozoic or saprophytic or holophytic, while in the Cryptomonads starch is produced and nutrition is 
never holozoic. Pascher has shown, however, that although starch is formed in certain Cryptomonads (Cryptomonas erosa, Chroomonas baltica, Chrysidella, Chilomonas), this is not the case in other forms which have been investigated (Protochrysis, Cryptochrysis, Chroomonas Nordstedtii) nor in the Phæocapascæ, where the assimilate is either leucosin or oil. All that can be said on this head is that solid assimilation products are relatively rare in the Chrysomonads and relatively common in the Cryptomonads. Again, the beginnings of the characteristic furrow of the Cryptomonads are seen in the Ochromonadales, and even in the Chromulinales, where the anterior end of the body shows a pit in which the flagellum is inserted. 
TROM simple Cryptomonads-like Protochrysis, Cryptochrysis, or Wysotzkia-various diverging lines may be traced. One of these leads to the endozoic "Zooxanthella" forms; some at any rate of the "Zooxanthellæ" belong to the Cryptomonads and are placed by Pascher in a new genus, Chrysidella. Two other lines, marked by the fixation of the blue-green and the red chromatophores found sporadically in the simpler Cryptomonads, lead respectively to the blue-green genera Chroomonas and Cyanomonas and to the red genus Rhodomonas. Another line leads to Cryptomonas and Nepliroselmis, with firm periplast, and from these have been derived the colourless forms Chilomonas, Cyathomonas, and Oxyrrhis. The fifth line has probably led to the Dinoflagellata (Peridiniales) on one hand, and through simple palmelloid types to the Phæocapsaceæ on the other. In the Phæocapsacex, beginning with simple gelatinous forms like Pliceoplax, Plicocystis, and Phloococcus, we have a series of transitional types leading to the definitely filamentous Phaothamnion and so to the Ectocarpales.

The inter-relationships of the Brown Flagellate and Algal groups as here suggested are indicated on the accompanying scheme (Table C).

\section{VIII.-The Peridiniales (Dinoflagellata) and their ReLationships.}

The Peridiniales, mainly marine but also found in fresh waters, and often forming a considerable part of the microplankton, are always unicellular and usually isolated, though sometimes cohering in chain-like colonies and in one family (Phytodiniacer) forming palmelloid aggregations by repeated division within gelatinous envelopes. There are typically two dissimilar flagella, usually lodged in grooves-one longitudinal and the other transverse-and in most cases the protoplasm is clad by a cellulose wall, typically built up of a series of sculptured and perforated plates. Oil is usually formed as the product of anabolism, even in forms possessing pyrenoid-like bodies, but in a few cases starch is produced. Most of the Peridiniales have yellow or brown or (in some freshwater species) green chromatophores, usually numerous and band or rod-like and radially arranged, but sometimes these are absent or represented by leucoplasts-these colourless forms are mostly saprophytic or in some cases holozoic, while Dogiel (41) and Chatton $(21,22)$ have recently shown that certain forms are 
parasitic on various animals. Reproduction takes place by division into two or more daughter cells (spores or zoogonidia) and resting cysts are also formed by rejuvenescence of the cell contents. However, the life cycle of very few forms has yet been worked out,

P H A E O P H Y C E E

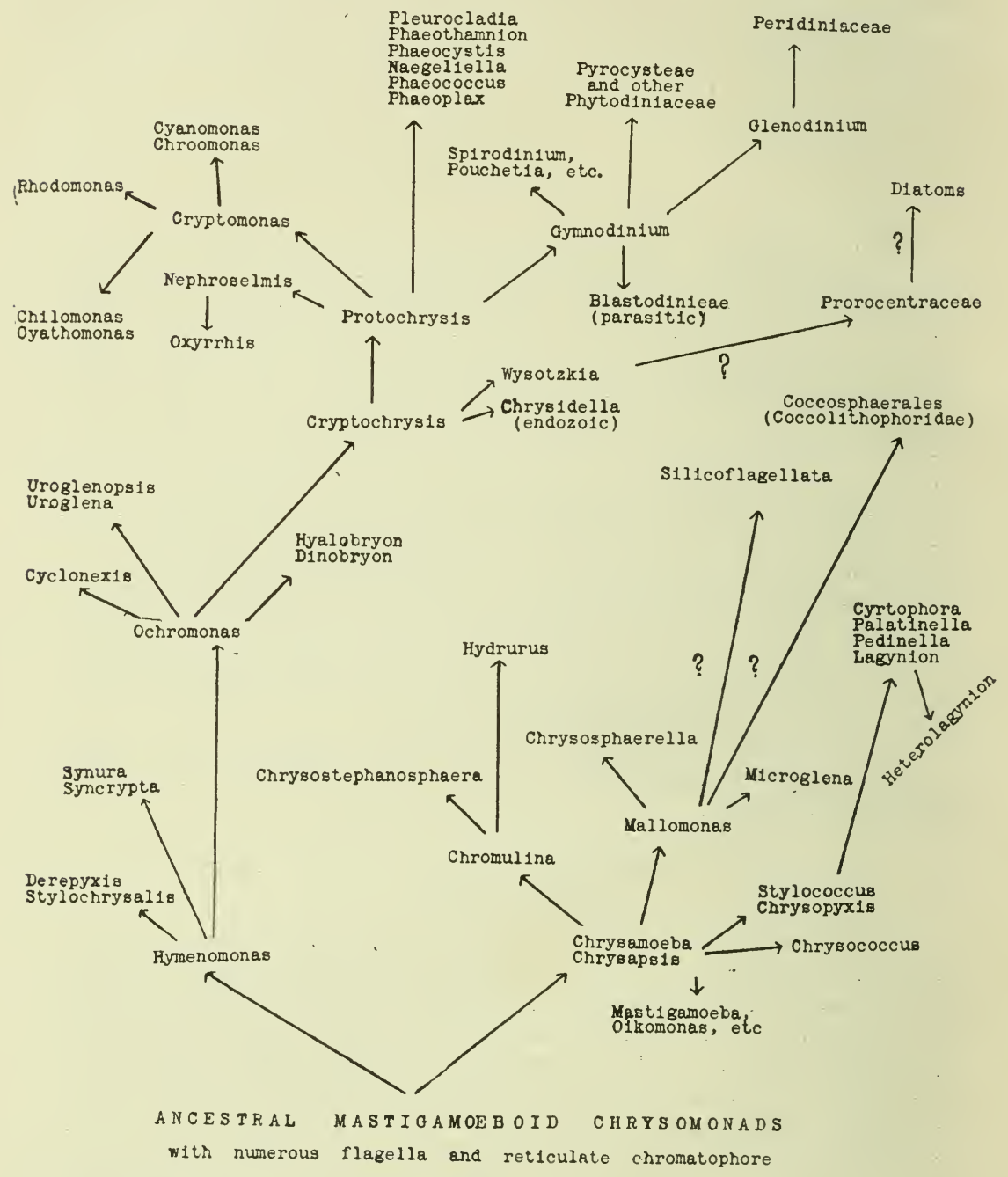

CHLAMYDOMONADS
POL YBLEPHARIDS

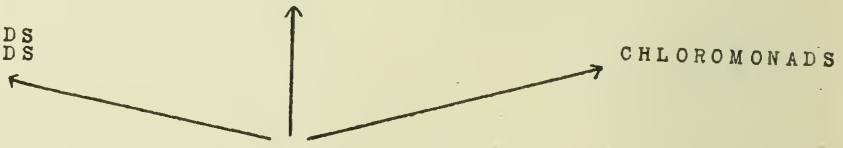

A utotrophic Multic1lia-like

Mast 1 Bamoebo1d Ancestors

Table C.-Suggested Phylogeny of Brown Flagellate and Brown Algal Series, For details see Text. 
despite the voluminous literature that has accumulated as the result of the collection of plankton Peridiniales, at all times of the year, by numerous workers; there is, for instance, no proof at present that a sexual process occurs in the group-unless we include in it the genus Noctiluca (see below). Zederbauer (157) observed individuals of Ceratium Hirundinella, a freshwater species, grouped in pairs and connected by protoplasm, while the contents of other individuals had been extruded in the form of a cyst-whence he inferred that zygospores had been formed as the result of a conjugation process. However, Jollos (62) and Wesenberg-Lund (145) observed the formation of similar cysts in Ceratumm which had certainly arisen without copulation, and it would appear that the paired cells seen by Zederbauer had arisen as the result of abnormal cell division or that the process may be simply one of plastogamic fusion such as occurs in certain Protozoa.

Schütt (134) divided the Peridiniales into three familiesGymnodiniacex, Prorocentracex, and Peridiniaceæ. In the Gymnodiniacere the cell is naked or clad only by a thin mucilaginous or cellulose wall showing uniform structure and in most cases forming merely a delicate periplast like that of the majority of Flagellata. Of the two flagella, one is directed backwards in the longitudinal groove (sulcus) while the other (usually thrown into undulating curves) lies in the transverse groove (annulus). Both sulcus and annulus may be straight, meeting at right angles at one point where the flagella arise-in this case the annulus is either subequatorial (complete in Gymnodinium, a half-ring in Hemidinium) or is near the anterior pole so that the anterior (præ-annular) portion of the cell is much smaller than the posterior and is rostrum. like (Amphidinium); or the annulus may be spirally coiled and the sulcus slightly (Spirodinium) or markedly (Cochlodinium, Pouchetia) spiral also, meeting the annulus at both ends, with the transverse flagellum inserted at the anterior end of the annulus and the longitudinal flagellum at the posterior end of the sulcus-Pouchetia is distinguished from Cochlodinium by having a complicated stigmatic apparatus consisting of a red or blacls pigmented body with one or more large spheroidal refractive lens-like bodies adjoining it. In this family Schütt includes Pyrocystis (see below).

In the Prorocentracer (Fig. 8) there is a shell consisting of two biconvex valves, dotted with pores except on either side of the suture; from an opening in this suture, at the anterior end of the cell, arise the flagella, of which one is directed forwards while the second either vibrates about the base of the first or is directed laterally. In the three genera included here by Schütt, there are usually two large plate-like chromatophores, one lying within each valve of the wall, but sometimes these are deeply lobed or even divicled into a number of radiating elongated chromatophores, as in the majority of Peridiniales. In Cenchridium the pore from which the flagella arise is continued inwards as a gullet-like tube; in Exuvialla and, more markedly, in Prorocentrum, there are small projections of the wall close to the flagellum pore, which Schütt suggests may represent the beginnings of the characteristic winglike expansions of the margins of the flagellum groove in the Peridiniaceæ. 
The remaining Peridiniales are placed by Schüt in the family Peridiniacex, in which the shell differs from that of the Prorocentracez in having a series of girdle plates intercalated between the two valves. The girdle consists essentially of a narrow ringlike plate with a groove (annulus) for the transverse flagellum, and a pair of plates (sometimes each divided into several plates) placed at right angles to this and containing the longitudinal groove (sulcus). Each valve consists of two or more polar plates, which are either joined directly to the girdle series or are separated by intercalary

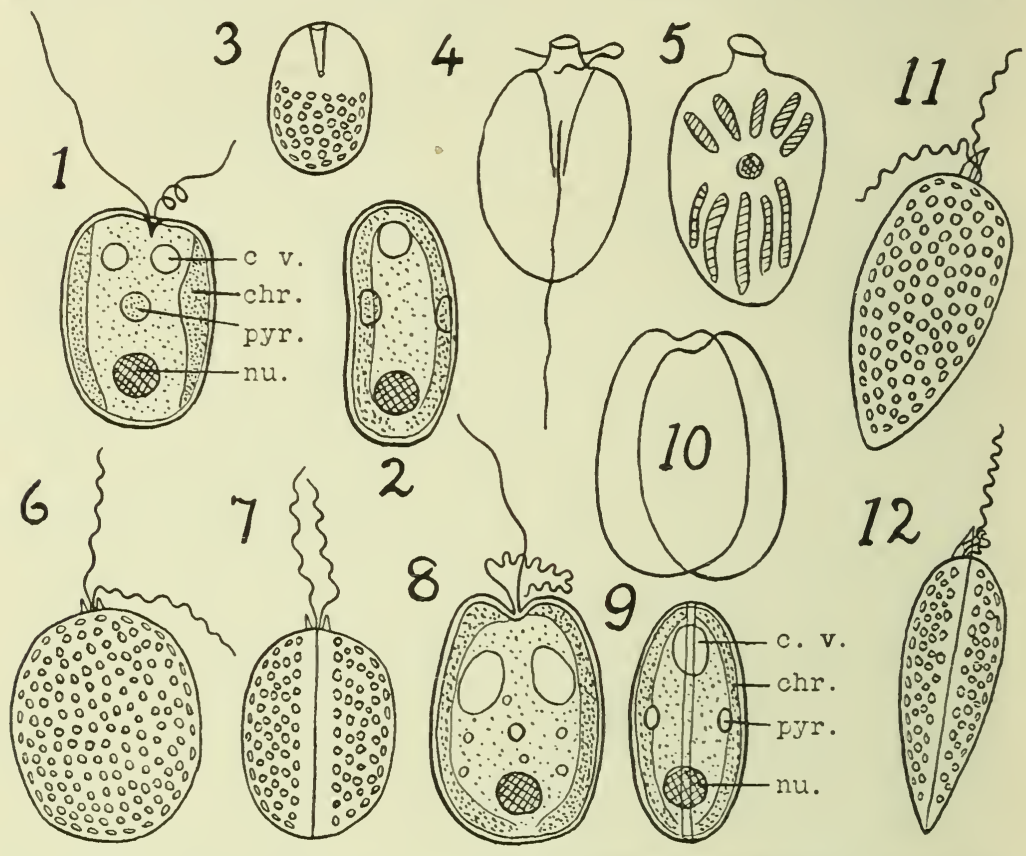

Fig. 8. Prorocentracez.-1, 2, Haplodinium antjoliense Klebs : 1, surface view ; 2 , side view ; 3, Cenchridium globosum (Williams) Stein. 4, 5, Amphidinium operculatum Clap. et Lach.; 4, ventral view, showing the flagella; 5 , dorsal view, showing nucleus and chromatophores. 6 to 10, Exuvialla marina Cienk. : 6 and 7 , two aspects at right angles to each other, showing the flagella and the surface markings of the shell; 8 and 9 , optical sections corresponding respectively with 6 and 7 , and showing the nucleus, chromatophores, pyrenoids, and contractile vacuoles; 10 , empty valves of the shell, after escape of encysted contents. 11 and 12 Provocentrum micans Ehrb., two views at right angles. $C h r$. , chromatophore ; $c . v$. , contractile vacuole; $n u$., nucleus ; $p y r_{.}$, pyrenoid.

$1,2,8,9,10$, from Klebs ; 3, 4, 5, from Stein; 6, 7, 11, 12, from Schït. All somewhat diagrammatic.

plates. The upper valve (epitheca) bears an apical pore, and in most cases the sulcus is confined to the lower valve (hypotheca), though sometimes it extends beyond the annulus right to the apex of the cell (Steiniella, Gonyaulax), or it may be short and extend equidistantly on either side of the annulus (Protoceratium). Schütt divides the Peridiniaceæ into four sub-families-Glenodinieæ (only genus Glenodinium); Ptychodiscer (only genus Ptychodiscus); Dinophyseæ (six genera, including the most bizarre forms of 
Peridiniales); and Ceratiex (C'eratium, Peridinium, etc.-this is the largest division of the group). In the Dinophyser the shell is divided by a longitudinal suture into two subequal lateral portions; the epitheca is much smaller than the hypotheca, the borders of the annulus are funnel-like and the left-hand border of the sulcus is often developed into wings and spines.

According to Schüt, the Peridiniacere are connected with the Gymnodiniacer by the genus Glenodinium, and with the Prorocentrace by the genus Ptychodiscus. In Glenodinium (Fig. 9, 9 to 13) the shell is thin and structureless (not sculptured or perforated), and its differentiation into two valves and a girdle is only apparent when rupture occurs at liberation of the encysted contents. In Ptychodiscus the two valves have the same structure as in the Prorocentracere, but the girdle is represented by a thin soft membranous ring-like band, while the sulcus is indicated by a depression on one valve and a narrow plate on the other.

The results of recent work suggest considerable modifications of Schütt's classification of the Peridiniales, and appear to afford a basis for phylogenetic interpretations very different from those put forward by that author in 1896. Our knowledge of the Peridiniales and allied groups has been greatly extended in recent years by the work of Apstein $(1,2)$, Borgert (13), Chatton $(21,22)$, Dogiel (41), Jollos (62), Klebs (68), Kofoid $(71,72)$, Lemmermann (75-85), Lohmann (86-88), Schilling $(127,128)$, and other's; the literature is cited by Pavillard (115) and in various other general works.

The view that the Peridiniales are related to the Flagellata appears to have been first put forward by Bergh (4), who pointed out the striking resemblances between Prorocentrum and the Cryptomonads. Bergh also suggested that a form like Prorocentrum might have given rise to the Dinophyser, in which the transverse groove is near the anterior end of the cell, and that the Ceratiex are derived from the Dinophysea by progressive shifting backwards of this groove to an approximately median position. Bütschli (18), on the other hand, considered that in the evolution of the Peridiniales shifting of the annulus had taken place from behind forwards; according to his interpretation of the structure of Proro. centrum, which is followed by Schütt, the suture between the two valves is horizontal, and the insertion of the flagella lateral. Bergh and Bütschli agreed in regarding the simple shell-less Gymnodiniaceæ as derived by reduction from the typical shell-clad Peridiniales, and various other writers have adopted this view, as being a necessary consequence of the principle that the Peridiniales are of monophyletic origin.

A much simpler interpretation is obtained if we regard the suture in the Prorocentraceæ as being longitudinal and as corresponding with the longitudinal suture in the Dinophyseæ, which ought perhaps to be separated as a distinct family-the higher Peridiniales (Schütt's Peridiniaceæ) would then fall into two families, Ceratiacex and Dinophysidaceæ. Including the two families recently founded by Klebs and by Chatton, the Peridiniales as a whole may be regarded as forming two distinct series, which it is here suggested are of independent origin from the Cryptomonads. 
The Gymnodiniacex (Fig. 9) may well have arisen from a Cryptomonad like Protochrysis, with two unequal flagella arising from a lateral depression having the form of an incomplete transverse groove. In the Gymnodiniacer, however, there are numerous chromatophores instead of two, and the nucleus, as pointed out by Klebs (68) has a characteristic fibrillar structure apparently not found in the Chrysomonadinex. But granting these differences, and the absence of what may be strictly regarded as transitional

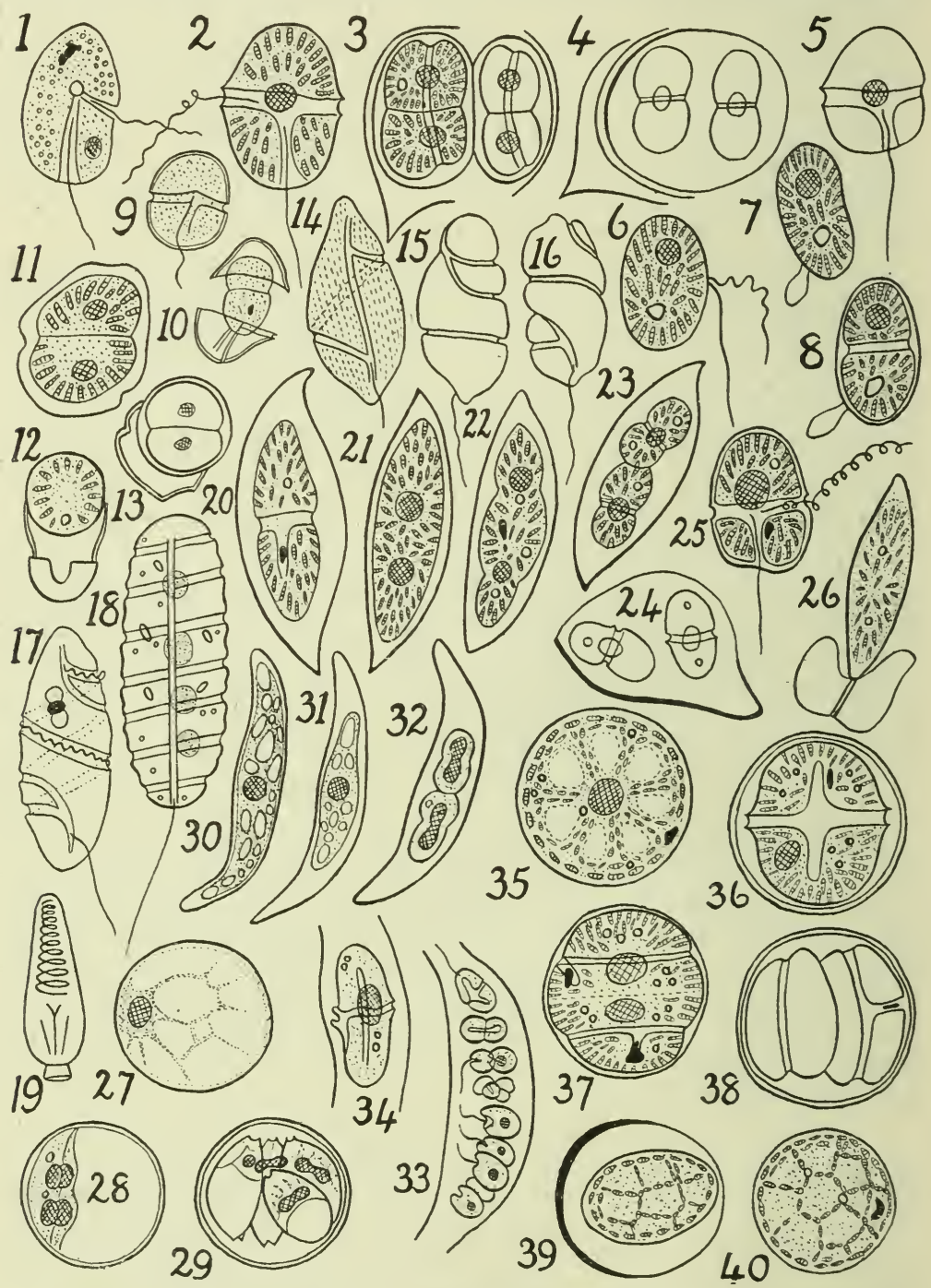

Fig. 9. Gymnodiniaceæ.-1, Hemidinium nasutum Stein, showing flagellum grooves, flagella, nucleus, and numerous small chromatophores. 2 , Gy'mnodinium bogoriense Klebs. 3 to 8 , Gymnodinium rotundatum Klebs: 1, two cysts enclosed in the membrane of the parent cell ; 2, rupture of cyst shown on the left in preceding figure, to set free the two motile cells; 5 , motile cell; 6 , the 
same gradually coming to rest and about to lose its flagella; 7 , the same after loss of flagella, secreting a drop of mucilage for attachment ; 8, the same, two days later (the transverse furrow which had disappeared on coming to rest has now been re-formed). 9, 10, Glenodinium pulvisculus Ehrb.: in 10 one of the shell-valves has been forced off to allow escape of the spore, which soon afterwards undergoes division. 11 to 13 , Glenodinium emarginatum Klebs : in 11 the ccll contents have undergone oblique longitudinal division; 12 shows escape of contents as a spore (cyst), and 13 the division of this cyst. 14, Spirodinium spirale (Bergh) Schütt. 15, 16, Cochlodinium strangulatum Schütt. 17, Pouchetia fusus Schütt, showing the spirally coiled flagellum grooves, and the stigma (consisting of a pigment-body with a refractive lens-like body on either side of it. 18, 19, Polykrikos auricularia Bütschli : in 18 the longitudinal flagellum groove, eight transverse grooves, four nuclei, and five trichocysts ; 19, a trichocyst. 20 to 26, Cystodinium bataviense Klebs : 20, cyst with Peridinean body ; 21 to 23 , stages in division of cyst contents into two cells, which escape by gelatinisation of one side of the cyst (seen in 24$) ; 25$, motile cell ; 26, motile cell has become a cyst, set free by rupture of the cell-wall; the black fleck in 20,22 , and 25 is a stigma ("eye spot"). 27 to 34 , Diplodinium lunula (Schütt) Klebs (= Pyrocystis lumula Schütt) : 27, uninucleate primary cyst; 28 , cyst with four nuclei, the cytoplasm not yet divided; 29 , cyst with four cells, each about to divide again; 30 , sickle-shaped secondary cyst ; 31 , contraction of contents of same; 32, 33, division of contents into motile Gymnodinium-like cells, of which one is shown more highly magnified in 34.35 to 40 , Hypnodinium spharicum Klebs; 35 , a cell in optical section, showing the central nucleus, the numerous small chromatophores in the peripheral and radiating portions of the cytoplasm, an "eye spot," and five orange-red oil drops; 36 , cell with rounded off contents showing Gymnodinium-like grooves; 37, stage in division, showing two nuclei, two transverse grooves, and two "eye spots"; 37 , division into two Gymnodinium-like cells completed; 39 , 40, rupture of cyst, setting free the two daughter cells, which have now lost their grooves.

$1,9,10$, from Stein ; 2 to 8,11 to 13,20 to 26,35 to 40 , from Klebs ; 14 to 17, from Schütt; 18, 19, from Bergh.

forms, there appears to be little doubt that the discovery of Protochrysis has at any rate lessened the gap between the Cryptomonads and a simple Peridinean genus like Hemidinium with its incomplete transverse groove. From a form like Hemidinium, the transition is easy to Gymnodinium and to Glenodinium (which is best placed in the Gymnodiniacer and which forms a connecting link with the Ceratiaceæ). These simple Gymnodiniaceæ form a central group from which diverge lines leading in various directions. In Spirodinium, Cochlodinium, and Ponchetio the cell is elongated and the grooves spirally coiled, and the pigmented body (stigma) found in the simpler forms is accompanied in Pouchetia by one or more lens-like bodies. In Pcuchetia armata (Dogiel, 41) the cell is provided with nettling organs (trichocysts) consisting of a conical capsule containing a coiled stinging thread. Nettling organs of this kind are also found in the remarkable naked holozoic genus Polykrikos (Bütschli, 18 ; Koloid, 72), in which the elongated body has eight transverse grooves and a single straight longitudinal groove, and there are eight nuclei-according to Delage (37) these are meganuclei, accompanied by smaller nuclei (micronuclei) as in Ciliate Infusoria, and each transverse groove has a flagellum. From Kofoid's account of Polykrikos, it would appear that the apparently single cell is a colony of individuals arranged in a linear series, owing to incomplete separation after division; Dogiel (41) has described specimens with four transverse grooves and a single nucleus. Polykrikos may be definitely placed in the Gymnodiniacer, since the presence of nettling organs in Pouchetia connects it with Cochlodinium and Spirodinium and thus with the simpler genera 
like Gymnodinimm. Whether Polykrikos forms a link between the Peridiniales and the Ciliate Infusoria is, of course, an open question in the absence of further transitional types. It is possible that the genus Erythropsis (Hertwig, 57 ; Delage, 37 ; Pavillard, 114) affords such a transition; in this organism the irregularly sphericai body shows a longitudinal groove, a transverse groove with a wavy flagellum at the anterior end of the body, and a relatively thick contractile outgrowth at the posterior end, while there is a stigmatic apparatus comparable with that of Pouchetia. Hertwig regarded Erythropsis as an Infusorian allied to Vorticella; while Metchnilsoff compared its appendage to the sucker of Acineta and placed the genus in the Suctorial Infusoria. It is probable that the resemblances to Infusoria presented by Polykrikos and Erythropsis are merely superficial or due to homoplasy; in any case, both genera appear to be directly related to the Gymnodiniacex.

The life cycle of the lower Gymnodiniacex, so far as known, is extremely simple. In some cases division occurs in the motile condition, but more usually after encystment, the cyst being covered by gelatinous envelopes or by a firm wall and its contents dividing into two or more cells. In Cystodinium (Fig. 9, 20-26) the motile cells resemble Gymnodinium in structure, but on becoming encysted they acquire an elongated and horned form, the contents then become rounded off and dividing to produce two or four motile cells. In Diplodinium (Fig. 9, 27-34) the life cycle is somewhat complicated, since the encysted cell divides to form sixteen secondary cysts, each of which gives rise to four, eight, or sixteen motile Gymnodinium-like cells; to this genus Klebs refers Pyrocystis lunula and certain species which had previously been placed in the genus Gymnodinium. Finally, Hypnodinium (Fig. 9, 35-40) is known only in the resting stage; on becoming encysted, the protoplast shows Gymnodiniumnlike grooves and divides into two naked cells exactly like Gymnodinium but without flagella-on being set free by rupture of the cyst these two cells acquire a membrane and soon form new cysts.

In the genera Blastodinium and Apodinium, recently discovered by Chatton $(21,22)$, and perhaps best placed in a family (Blastodiniacere) distinct from but closely allied to the Gymnodiniacex, which live as parasites or commensals in the bodies of Copepods and other marine animals, the cell divides into two portions, of which one continues the ordinary vegetative cycle while the other divides into a number of cysts which are set free as biflagellate Gymnodinium-like cells.

The genus Diplodinium leads from the Gymnodiniacer to the family Phytodiniaceæ (Fig. 10, 1-13), which includes the old genus Pyrocystis (minus P.lunula,now transferred to the genus Diplodinium) and four new genera founded by Klels (68). In this family the cells show Peridinean cytological features, though no grooves are present; reproduction takes place by simple division of the cell contents into two, but no motile cells have been observed. The simplest form is Phytodinium, with ovoid cells (Fig. 10, 1,2); in Pyrocystis (Blacliman, 8) the protoplasm is radially arranged, and is massed together at one end of the cell, very much as in the primary cyst of Diplodinium lunula; in Tetradinium (Fig. 10, 3.7) 
the cell is tetrahedral, with two pointed processes at each angle; in Stylodinium (Fig. 10,8,9) the oval or spherical cell is attached to a substratum by means of a gelatinous stalk ; while in Gloodinium

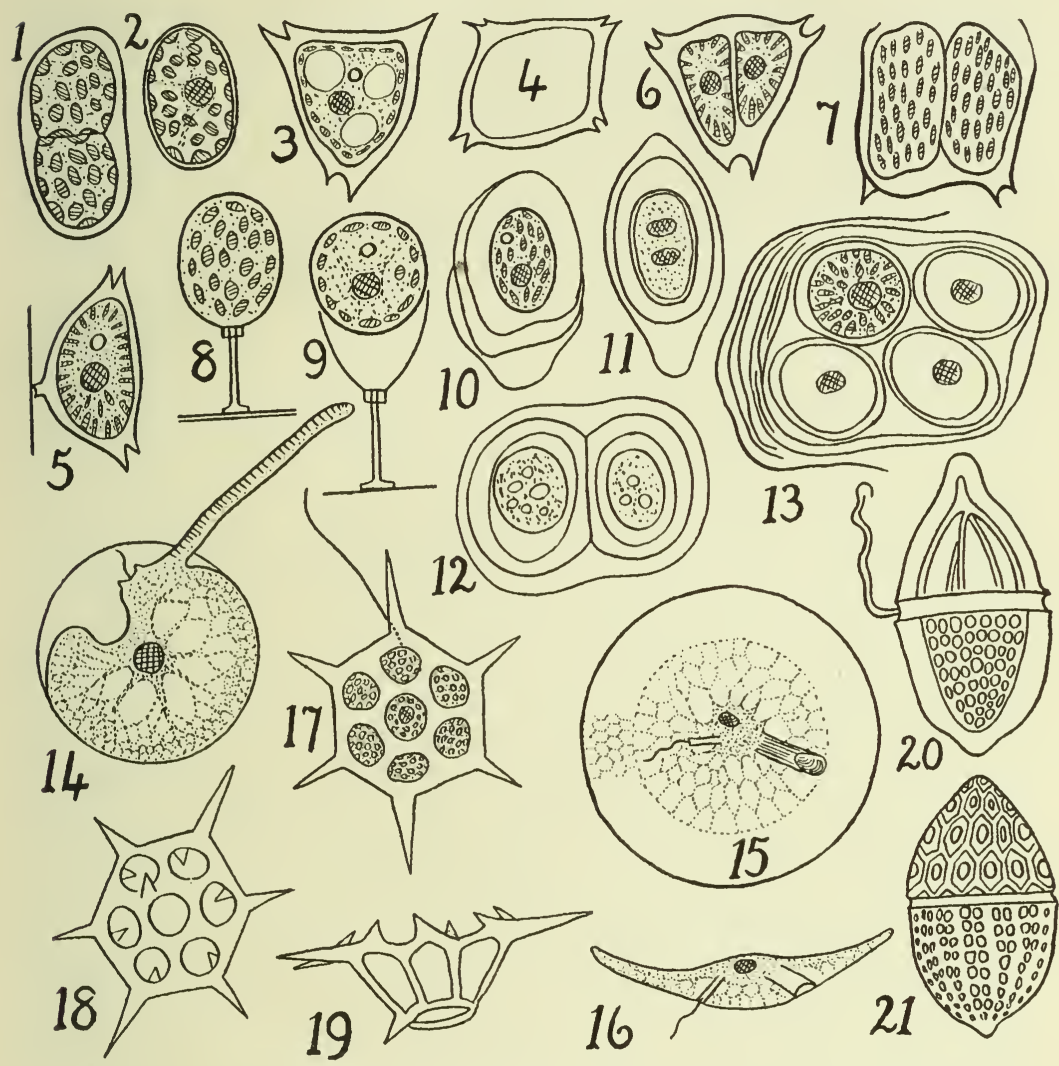

Fig. 10. Phytodiniacese (1 to 13 ), Cystoflagellata (14 to 16 ), and Silicoflagellata (17 to 21 ).

1, 2, Phtvodinium simplex Klebs: in 1 the cell has divided, in 2 the nucleus is shown. 3 to 7, Tetradinium javanicum Klebs: 3 , cell showing vacuolate cytoplasm, nucleus, an oil-drop, and numerous peripheral chromatophores ; 4 , empty cell, showing all four angles ; 5 , cell attached to a root-hair of $A$ zolla ; 6, division ; 7, escape of the two daughter-cells from ruptured cyst-ivall. 8, 9, Stylodinium globosum Klebs : 8, stalked cell attached to a root-hair of Azolla ; 9, escape of undivided contents by rupture of old cell-wall. 10 to 13 , Glocodinium montanum Klebs : 10, cell with several gelatinous envelopes derived from older membranes; 11 , division of the nucleus; 12 , cell division; 13, older colony surrounded by gelatinous envelopes. 14, Noctiluca miliaris Suriray: side view (optical section), showing on the left the short flagellum inserted in the "pharynx," at the base of the thick tentacle. 15, 16, Leptodiscus Hertivig: 15 , surface view, ventral side, showing on the right a wide depression with striated walls and on the left the narrow tube containing the flagellum; 16 , side view (optical section). 17 to 19, Distephanus speculum Stöhr: 17, cell showing skeleton and cell-contents (nucleus, cytoplasm, chromatophores); 18,19 , two views of skeleton. 20, Monaster rete Schütt : side view, showing the two flagella arising from equatorial groove, and the internal skeleton. 21, Amphitolus elegans Schïtt : side view, showing the elaborate skeleton.

1 to 13 , from Klebs; 14 to 19 , from Delage ; 20, 21, from Schïtt. 
(Fig. 10, 10-13), the most Alga-like form, colunies of considerable size are formed by repeated division within a thick stratified gelatinous investment.

The Noctilucacez' (Cystoflagellata) are probably derived from Pyrocystis-like Peridiniales. In Noctiluca (Fig. 10,14) the spherical cell shows great resemblance in internal structure to Pyrocystis, though there is no cell-ivall and there are, on the other hand, some elaborations not found in Pyrocystis-e.g., the thick tentacle which is transversely striated and shows movements, the short flagellum in the gullet-like opening guarded by two projections ("tooth" and "lip"). The reproduction of Noctiluca is a somewhat remarliable process-after conjugation of two cells budding occurs, and from the buds there arise motile cells which show Gymnodinium-like features - a transverse groove (without flagellum, however) and on the concave ventral side a backwardly directed longitudinal flagellum. The other genera of the family-Leptodiscus (Fig. 10, 15, 16) and Craspedotella (Kofoid, 71)-also show specialised structure, and do not serve to fill the gap between Noctiluca and Pyrocystis; in Leptodiscus the cell has the form of a watch-glass, the convex ventral surface having a wide gullet-like depression on one side, and on the other and a narrow pit containing a flagellum, while Craspedotella resembles a medusa in form.

Reference has already been made to a possible connection between Gymnodiniaceæ and the Infusoria. Certain organisms are also known which appear to lead from the Peridiniales to another group of Protozoa-the Radiolaria. The flagellated spores produced by various Radiolaria (for details and some of Brandt's figures of these, see Gamble's account of this group in Lankester's Treatise on Zoology, 151) present an extraordinarily close resemblance to Gymmodinimm and other simple Peridiniales, and suggest the origin of this Protozoan group from Gymmodinimm-like ancestors. Moreover, Schütt has described three genera which appear to form direct links between Gymnodiniacere and simple Radiolaria, and which also suggest the possible origin of the Diatoms; these genera (Gymnaster, Monuster, Amphitolus) have an internal slieleton which recalls that of Radiolaria, and the body is divicled into two portions by an equatorial suture, which in Amplitolus (Fig. 10, 21) and Monaster (Fig. 10, 20) is grooved, while in Monaster the resemblance to Peridiniales is enhanced by the presence of two flagella inserted in this groove and springing laterally from the body. In addition, Borgert has shown that certain genera-Disteplanus (Fig. 10, 17-19), Mesoscena, Dyctiocha, Cannopilus-which had been previously placed in the Radiolaria (in the bodies of which they live as commensals, and with which they agree in having a siliceous slieleton) are Flagellate forms, for which he formed the group Silicoflagellata (see also Lemmermann, $80,83)$; these organisms have a sleleton consisting of transverse rings which are either free or joined up by longitudinal spicules to form a network, and in the genera named there is a single flagellum (Borgert's new genus Ebria has two flagella), while the protoplasm contains numerous yellow chromatophores. The Silicoflagellata may have been derived from forms lilie Monaster, or they may have come from Chrysomonadinean ancestors-certain Chrysomonads 
show a tendency to the formation of flinty sleeletons (e.g., Mallomonas, Chrysospharella). The Coccospharales (Coccolithophorida, 83, 86, 87) are perhaps derived from simple Chromulinales; in general morphology they resemble forms lile Chrysococcus, but with a peculiar armour consisting of calcareous plates instead of a homogeneous perisarc and suggesting comparison with the tesselated siliceous armour of Mallomonas, though until their cytology has been elucidated their affinities must remain in doubt.

In connexion with the Cryptomonads, mention may be made of two remarkable and somewhat aberrant Flagellate genera recently discovered by Scherffel,' the position of which in the scheme of classification above outlined appears to be doubtful. In one of these forms, Monomastix, there are two large laterally placed green chromatophores, each with a pyrenoid, and starch is formed; the cell shows dorsiventral symmetry and there is a single terminal flagellum. The other genus, Pleuromastix, is also a dorsiventral form, but has brown chromatophores and produces oil and probably also leucosin; it too has a single flagellum, inserted laterally at the obliquely truncate anterior end of the body. Scherffel inclines to the view that Monomastix belongs to the Polyblepharidacer, but Pascher (in reviewing Scherffel's paper in Zeitschr. f. Bot., Bd. 5, 1913 , p. 405) considers that its affinities lie rather with the Cryptomonads; both writers refer Pleuromastix, somewhat doubtfully, to the Chrysomonads. The most remarkable character common to these genera, apart from the possession of a single flagellum (all hitherto described Cryptomonads and Chloromonads have two Hagella, though one order of Chrysomonads, the Chromulinales, is characterised by a single flagellum) is the presence of peculiar structures somewhat resembling the trichocysts found in some Chloromonads (Rhaphidomonas, Merotricha) and Peridiniales (Polykrikos, see above) as well as in the Ciliate Infusoria. These trichocyst-like organs, especially well developed in the green form Monomastix, consist of a highly refractive outer layer and a less refractive central mass which on treatment with various reagents is protruded rapidly as a filament (in Plenromastix usually as a distinctly tubular structure). According to Scherffel, the structure of these organs in the two new Flagellates confirms the suggestion put forward by Künstler that the peculiar granular organs found lining the gullet-lile depression in the Cryptomonad body represent rudimentary trichocysts. Among the Ciliate Infusoria corresponding organs occur, in addition to more highly organised trichocysts, and it appears probable that in both cases structures of this kind are not always to be regarded as defensive organs but may be merely products of secretion. Apart from its possession of pyrenoids and starch, Monomastix might well be placed in the Chloromonads, but on the whole it would appear that both genera may be perhaps best classed provisionally among the Cryptomonads-as here treated, this is a somewhat varied and generalised one, with many divergent affinities.

' "Zwei neue trichocystenartige Bildungen führende Flagellaten." Arch. f. Protistenk., Bd. 27, 1912, pp. 94-128. 
IX.-Conclusion.

$W^{\text {HILE }}$ the recent work summarised here has led, through the discovery of interesting new species and genera and the re-investigation of forms previously known imperfectly, to a clearer knowledge of the Brown Flagellates and of the relations between these and the Brown Algr, it has thrown little further light upon the phylogeny of the Green Algr. The possibility that the Cryptomonads are related to the Chlamydomonads has been discussed by Fritsch (46), who admits, however, that the origin of the flagella from a depression and the obliquity of the cell in the Cryptomonads is against the view of a really close relationship. However, the Chrysomonadineæ and the lowest Chlamydomonads-the Polyble- 
pharidaceæ-may well have arisen from a common ancestral form, which we may imagine to have been multiflagellate and amœboid, with a basin-shaped chromatophore. Apart from the differences in flagellum number and the nature of the assimilate we find corres. ponding simple "mastigamoboid" forms in each of the orders of Chrysomonadinea-e.g., Chrysamoba, Hymenomonas, Ochromonas, Wysotzkia; while the Chloromonad genus Chloramoba suggests the origin of the Chloromonadineæ from a similar ancestral form by the division of the primitively single basin-shaped chromatophore into a number of small chloroplasts. If the multiflagellate condition is taken as primitive, we must regard the Polyblepharidaceæ, which also have a limited power of change of shape, as being nearer to the ancestral stock than any of the other coloured Flagellate and lower Algal forms.

The nearest approach to such an ancestral form is the colourless Multicilia, with two species, of which M. lacustris is multinucleate while $M$. marina has a single nucleus; in both species, the spherical body bears numerous radiating flagella, food is ingested by pseudopodia which may be put out from any point, there are numerous peripheral contractile vacuoles, and division occurs by median constriction of the body as in Amoba. Probably the primitive form of chromatophore was a reticulate peripheral sheet immediately within the periplast, and when the flagella became restricted to the anterior end of the body this sheet would become basin-shaped (i.e., open anteriorly) as in the majority of Volvocales and in various Chrysomonads, or on the other hand broken up into numerous small chromatophores, as in Chloromonadiner, Gloomonas (allied to Chlamydomonas), Chrysococcus dokidophorus (Chromulinales), etc. A reticulate chromatophore occurs in Chrysapsis (one of the most primitive Chrysomonads), and in certain Volvocales (Spharella, Chlorogonium). The bell-shaped chromatophore which is characteristic of the Volvocales and of the simpler Chrysomonadinez has undergone longitudinal splitting in at least one genus (Scherffelia) in the former group and in the majority of the Chrysomonadinex, giving rise to two lateral curved band-like chromatophores; these two types of chromatophore may occur in different species of the same genus, as is seen in Uroglenopsis (Ochromonadales).

If, while bearing in mind Vuillemin's timely caution against dogmatism in such matters, we assume that autotrophic organisms are primitive and heterotrophic organisms derived, and that the Flagellata represent the most primitive organisms known to us, the striking parallism which has been shown to exist between the Brown Flagellates and certain colourless Flagellates suggests the view that the whole of the latter may have arisen from coloured autotropic forms by adaptation to heterotrophic modes of nutrition. On this view, the classification of the Flagellata which has hitherto been accepted is purely physiological, and therefore artificial, corresponding with the conventional division of the Thallophyta into Algæ and Fungi ; and the various groups of colourless Flagellates will doubtless be shown, on further investigation, to have arisen from corresponding forms among the coloured Flagellates, just as the various groups of Fungi are now regarded as arising from corresponding Algal forms. Of the many lines starting from a hypothetical autotrophic Multicilia-like ancestral form, with a reticulate chromatophore, 
numerous peripherally situated nuclear bodies, and numerous flagella, some have ended blindly and produced nothing higher than Flagellates - a few of these remaining autotrophic but the majority becoming adapted to various modes of heterotrophic nutritionwhile three may be traced into the Vegetable Kingdom and lead respectively (i) through the Polyblepharids to the Chlamydomonads and thence to the majority of Green Algæ, (ii) through the Chloromonads to the Confervales, and (iii) through the Chrysomonads to the Cryptomonads and thence to the Phrophycer, the Peridiniales, and probably the Diatoms.

The origin of the remaining Algal groups from Flagellata is much more difficult to trace, owing to the absence of transitional forms. There are no forms whatever which would serve to connect the Blue-green and the Red Algæ with the known Flagellates of corresponding colour; it is much more likely that the Cyanophyceæ are related to the Bacteria, while the Rhodophycex may have been derived from the same stock as the Dictyotaceæ, which occupy a somewhat isolated position among the Phæophyceæ. The origin of the Diatoms is an equally open question; it seems lilely, at any rate, that they are related to the Peridiniales or to the Chryso. monads rather than to the Conjugatæ.

\section{LITERATURE REFERRED TO.}

The following list of literature on the Flagellata and Primitive Algæ is not intended to be exhaustive. Reference should be made to the literature lists given by Bütschli (18), Calkins (19), Delage (37), Doflein (40), Fritsch (46), Klebs $(67,68)$, Lotsy (89), II'Keever (91), Minchin (93), Oltmanns (95), Pascher (101), Pavillard (114), Scherffel (125), Schütt (134), Senn (135), Stein (138), Wille $(149,150)$, IVilley and Hickson (151).

1. Apstein, C. "Die Pyrocysteen der Plankton-Expedition." Wrss. Ergebnisse d. Plankton-Exp. d. Humboldt-Stiftung, Bd. 4, 1902, pp. 1-27.

2. ", "Pyrocystis lunula und ihre Fortpflanzung." WViss. Meeresunters., Kiel, N.F.Bd. 9, 1906.

3. Bachmann, H. "Chlamydomonas als Epiphyt auf Anabana flos-aqua." Ber. d. deutsch. bot. Ges., Bd. 23, 1905, pp. 159-161.

4. Bergh, R. S. "Der Organismus der Cilioflagellaten." Morphol. Jahrb., Bd. 7, 1881 .

5. Bergon, P. "Les processes de division, de rajeunissement de la cellule, et de sporulation chez le Biddulphia mobiliensis Bailey." Bull. Soc. Bot. France, t. 54, 1907, pp. 327-358.

6. Blackman, F. F. "The primitive Algæ and the Flagellata." Annals of Botany, vol. 14, 1900 .

7. Blackman, F. F., and Tansley, A. G. "A revision of the classification of the Green Algre." New Phytologist, vol. 1, 1902.

8. Blackman, V. H. "Observations on the Pyrocystez." NEw PHytoLOGIST, vol. 1, 1902, pp. 178-188.

9. Bohlin, K. "Zur Morphologie und Biologie einzelliger Algen." Oefvers. K. Vet. Akad. Förhandl., 1897, pp. 507-527.

10. ", "Studier öfver nagra slägten af alggruppen Confervales Borzi." Bih.t. K. Sven. Vet. Akad. Handl., Bd. 23, Afd. 3, 1897 (Summary in Bot. Centralbl., Bd. 73, 18.98, p. 213).

11. "Utkast till de gröna algernas och archegoniaternas fylogeni." Upsala, 1901 (Summary in Bot. Centralbi., Bd. 87, 1901, p. 98).

12. Borgert, A. "Ueber die Dictyochiden." Zeitschr. für wiss. Zoologie, Bd. 51, 1891. 
13. Borgert, A. "Ueber ein Paar interessante neue Protozoenformen." Archiv für Protistenkunde, Bd. 9, 1907.

14. Borzi, A. "Botrydiopsis, nuovo genere di alghe verdi." Boll. d. Soc. Ital. d. Microscop., vol. 1, 1889, pp. 60-70.

15. ", "Studi Algologici." Palermo, 1895.

16. Brunnthaler, J. "Die Colonienbildenden Dinobryon-Arten (Subgenus Eudinobryon Lauterborn)." Verhandl. d. K. Zool.Bot. Ges., Bd. 51, 1901, p. 293.

17.

"Zur Phylogenie der Algen." Biol. Centralbl., Bd. 31, 1911, pp. 225-236.

18. Bütschli, O. "Protozoen", in Bronn's "Tierreich," Abt. 2, Mastigo. phoren, 1883-7.

19. Calkins, G. N. "The Protozoa." Columbia Univ. Biol. Series, 1901.

20. Campbell, D. H. " Notes on some Californian Green Algæe." Torreya, vol. 11,1911, p. 17.

21. Chatton, E. "Les Blastodinides, ordre nouveau de Dinoflagellés parasites." Comptes rendus Acad. Sci., Paris, t. 143, 1906, pp. 981-3.

22. " "Nouvel aperçu sur les Blastodinides (Apodinium mycetoides n.g., n.sp.)" Ibid., t. 144, 1907, pp. 282-5.

23. , ,

'Pleodorina californica à Banyul-sur-Mer' son cycle évolutif et sa signification phylogénetique." Bull. Sci. France et Belg., t. 43, 1911, pp. 309-331.

24. Chodat, R. "On the polymorphism of Green Algæe and the principles of their evolution." Annals of Botany, vol. 11, 1897.

25. ", "Algues vertes de la Suisse." Beiträge zur Kryptogamenflora der Schweiz, Bd. 1, Heft 3 ; Bern, 1902.

26. Conrad, W. "Note sur un état filamenteux du Symura uvella." Bull. Soc. Roy. Bot. Belg., t. 49, 1911, pp. 126-132.

27. Correns, C. "Ueber eine neue braune Süsswasseralge, Nageliella flagellifera, nov. gen. et spec." Ber. d. deutsch. bot. Ges., Bd. 10, 1892, pp. 629-636.

28. Dangeard, P. A. " Recherches sur les Algues inférieures." Ann. des Sci. Nat., Bot., Sér. 7, t. 8, 1888, 71 pp.

29. , "Recherches sur les Cryptomonadinze et les Eugleninz." Le Botaniste, Sér. 1, 1889, pp. 1-38.

30. ", "Contribution à l'étude des organismes inférieures." Ibid., Sér. 2, 1890, pp. 1-58.

31. $\quad$,

"Memoire sur les Chlamydomonadinées." Ibid., Sér. 6,1898 , pp. 66-198. 32. ", "Les Ancêtres des Champignons supérieurs." Ibid.,
Sér. 9,1901 , pp. 158-303.

33. ", "Etude sur le développement et la structure des organismes inférieurs." Ibid., Sér. 11, 1910, 311 pp.

34.

"Sur deux organismes inférieurs rencontrés au Laboratoire de Roscoff." Comptes Rendus Acad. Sci., Paris, T. 151, 1910, p. 765.

35. ", "Sur une Algue marine du Laboratoire de Concarneau." Ibid., T. 151, 1910, p. 991.

36.

"Recherches sur quelques Algues nouvelles ou peu connues." Le Botaniste, 1912.

37. Delage, Y. "La Cellule et les Protozoaires." Paris, 1896.

38. Dill, O. "Die Gattung Chlamydomonas und ihre nächsten Verwandten." Jahrb. für wiss. Bot., Bd. 28, 1895, pp. 323-358.

39. Dobell, C. C. "Structure and life history of Copromonas." Quart.Journ. Microscop. Sci., vol. 52, 1908, p. 75.

40. Doflein, F. "Lehrbuch der Protistenkunde." 3. Aufl., Jena, 1911.

41. Dogiel, V. "Beiträge zur Kenntnis der Peridineen." Mitt. d. zool. Station Neapel, Bd. 18, 1906.

42. Entz, G. "Uber die Organisationsverhältnisse einiger Peridineen." Math. u. Naturwiss. Ber. aus Ungarn, Bd. 25, 1907.

43. Francé, R. "Die Polytomeen, eine morphologisch-entwickelungsgeschichtliche Studie." Jahrb. für wiss. Bot., Bd. 26,1894 , pp. 295-378.

44. , ,

"Beiträge zur Kenntniss der Algengattung Carteria." Term. Füzetek, Budapest, vol. 19, 1896 (Summary in Beih. z. Bot. Centralbl., Bd. 6, 1896, p. 87). 
45. Francé, R. "Uber die Organisation von Chlorogonium Ehrb." Ibid., vol. 20, 1897 (Summary in Bot. Centralbl., Bd. 70, 1897, p. 197).

46. Fritsch, F. E. "The phylogeny and inter-relationships of the Green Algæ." Science Progress, vol. 4, 1910, pp. 623-648; vol. 5. 1911, pp. 91-110.

47.

"The occurrence of Pleodorina in the fresh water plankton of Ceylon." New Phytologist, vol. 3, 1904, p. 122.

48. Gardner, N. L. "Leuvenia, a new genus of Flagellates." Univ. of California Publications in Botany, vol. 4, no. 4, 1910.

49. Gobi, C. "Ueber" einen neuen parasitischen Pilz, Rhizidiomyces Ichneumon, und seinen Nährorganismus Chloromonas globulosa." Scripta Bot. Hort. Univ. Imp. Petropol., Fasc. 15. 1901, pp. 251-272.

50. Goldschmidt, R. "Lebensgeschichte der Mastigamöben." Archiv für Protistenkunde, Suppl., 1907, p. 83.

51. Goroschankin, J. N. "Beitrïge zur Kenntniss der Morphologie und Systematik der Chlamydomonaden." I., II. Bull. de la Soc. Imp. Moscou, 1890, 27 pp. ; 1891, 50 pp.; III., Flora, Bd. 94, 1905, pp. 420-3.

52. Griffiths, B. "On two new members of the Volvocacez." NEw Phytologist, vol. 8, 1909, pp. 130-7.

53. Hamburger, Clara. "Zur Kenntnis der Dunaliella salina und einer Amöbe aus Salinenwasser von Cagliari." Archiv für. Protistenkunde, Bd. 6, 1905.

54. Harper, R. A. " The structure and development of the colony in Gonium." Trans. American Microscopical Soc., vol. 31, 1912, pp. $65-83$.

55. Hartmann, M., and Chagos, C. "Flagellatenstudien." Mem. Ist. Oswaldo Cruz, Rio de Janeiro, vol. 2, 1909, pp·62-125.

56. Herdman, W. A. "On the occurrence of Amphidinium operculatum, Clap. et Lach., in vast quantity, at Port Erin (Isle of Man)." Journ. Linn. Soc., Bot., vol. 40, 1912, pp. 389-393.

57. Hertwig, R. "Erythropsis agilis, eine neue Protozoe." Morphol. Jahrb., Bd. 10, 1885, pp. 204-212.

58. Ishakawa, C. " Noctiluca miliaris." Journ. Imp. Coll. Sci., Tokio, vol. 6, pt. 4, 1894 ; also in Zool, Anz., Bd. 14, 1891, pp. 12-15, and in Ber. Naturforsch. Ges. Freiburg, 1894, pp. 1-12.

59. Iwanoff, L. "Beiträge zur Kenntnis der Morphologie und Systematix der Chrysomonaden." Bull. Acad. Imp. Sci., St. Petersburg, Sér. 5, t. 11, no. 4, 1899 .

60. " " "Beobachtungen über die Wasservegetation des Seengebietes." Biol. Sta. Bol., St. Petersburg, 1912, $152 \mathrm{pp}$. (in Russian: a German summary in Bot. Centralbl., Bd. 93, 1903, pp. 279-283).

61. Jacobsen, H. C. "Culturversuchen mit einigen niederen Volvoceen." Zeitschrift für Botanik, Bd. 2, 1910, pp. 145-188.

62. Jollos, V. " Dinoflagellatenstudien." Archiv für Protistenkunde, Bd. 19, 1910.

63. Karsten, H. “Die sogenannten 'Mikrosporen' der Planktondiatomen und ihre weitere Entwickelung, beobachtet an Corethron Valdiviae n. sp." Ber. d. deutsch. bot. Ges., Bd. 22, 1904.

64. ,

"Das Indische Phytoplankton." Wissensch. Ergebnisse d. deutschen Tiefsee-Expedition, 1907.

65. Keeble, F., and Gamble, F. W. "The origin and nature of the green cells of Convoluta roscoffensis." Quart. Journ. Microscop. Sci., vol. 51, 1907, pp. 167-219.

66. Kjellman, F. R., and Svedelius, N. "Ectocarpacex" in Engler und Prantl, Nachtrüge zum Teil 1, Abt. 2, 1909-1910.

67. Klebs, G. "Flagellaten-Studien." Zeitschrift für wiss. Zoologie, Bd. 55. 1893 , pp 265-445.

68. " " "Uber flagellaten-und algenähnliche Peridineen." Verhandl, Naturhist.-mediz. Vereines Heidelberg. N.F.Bd. 11, 1912, pp, 369-451.

69. Kofoid, C. A. "On Pleodorina illinoisensis." Bulletin Illinois State Lab. Nat. Hist., vol, 5, 1898-9, pp. 273-293. 
70. Kofoid, C. A. "On Platydorina, a new genus of the family Volvocoideae." Ibid., pp. 419-440.

71.

"Craspedotella, a new genus of the Cystoflagellata." Bull. Mus. Zool. Harvard Coll., vol. 46, 1905.

72.

"The structure and systematic position of Polykvikos Bütschli." Zool. Anzeiger, Bd. 21, 1907.

73. Lagerhein, G. "Ueber Phaocystis." Ofvers. kon. vet. Akad. Förhandl., Bd. 53, 1896, no. 4

74. 'Lauterborn, R. "Protozoenstudien." Zeitschrift für wiss. Zoologie, Bd. 59,1895 ; Bd. 65, 1899.

75. Lemmermann, E. "Zweiter Beitrag zur Algenflora des Plöner Seege bietes." Forsch. Ber. Boil. Plön, Teil 4, 1896.

76. $\quad$,

"Peridiniales aquæ dulcis et submarineae." Hedwigia, Bd. 39, 1900.

77. ,

“Diagnosen neuer Schwebealgen.' Ber. d. deutsch. bot. Ges., Bd. 18, 1900, Heft 7.

78. " "Notizen über" einige Schwebealgen." Ibid., Bd. 19, 1901, Heft. 2.

79. , ,

“"Die Gattung Dinobryon.” Ibid., Bd. 19, 1901, Heft 10.

80. ", "Silicoflagellateae. Ergebnisse einer Reise nach dem "Pacific." Ibid., Bd. 19, 1901, pp. 247.271.

81. " " "Die Algenflora der Chatham Islands." Engler's Bot. Jahrb., 13d. 38, 1901.

82. " " "Algenflora eines Moortümpels bei Plön." Forsch. Ber. Biol. Plön, Teil. 8, 1901.

83. ", "Flagellatæ, Chlorophycer, Coccosphærales, und Silicoflagellatæ." Nordisches Plankton, Lief. 2, Kiel, 1903, pp. 1-32.

84. ", "Das Plankton schwedischer Gewässer." Arch. Bot., Stockholm, Bd. 2, 1904.

85.

"Die Algen der" Mark Mrandenburg. Teil 1, Schizophyceen, Flagellaten, Peridinien." Berlin, 1910.

86. Lohmann, H. "Die Coccolithophoridæ, eine Monographie der Cocco lithenbildenden Flagellaten." Archiv. f. Protistenkunde, Bd. 1, 1902, pp. 89-165. Review in NEw Phytologist, vol. 1, 1902, p. 155, by V. H. Blackman, under title "Coccoliths and Coccospheres."

87.

"Untersuchungen über" die Thier-und Pflanzenwelt sowie über die Bodensedimente des Nordatlantischen Oceans." Sitzungsber. d. K. Pr. Akad. d. Wiss., 1903, pp. 560-583.

88.

"Das Nannoplankton." Internat. Revue der Hydrobiologie Bd. 4, 1911.

89. Lotsy, J. P. "Vorträge über botanischen Stammesgeschichte." Band 1 , Jena, 1907.

90. Luther, A. "Ueber Chlovosaccus, eine neue Gattung der Süsswasseralgen, nebst einigen Bemerkungen zur Systematik verwandten Algen." Bih. t. K. Sven. Vet. Akad. Handl,, Stockholm, Bd. 24, 1899. (Summary in Bot. Centralbl., Bd. 79, 1899, p. 188).

91. M'Keever, F. L. "Phcoothamnion confervicolum Lagerheim, and its first recorded appearance in Great Britain." Trans. and Proc. Roy.Soc. Edinburgh, vol. 24, 1911, pp. 176-18I.

92. Merton, H. "Ueber den B̈au und die Fortpflanzung von Pleodorina illinoisensis." Zeitschr. f. wiss. Zoologie, Bd. 90, 1908, pp. 445-474.

93. Minchin, E. A. "An introduction to the study of the Protozoa." London, 1912.

94. Ohno, N. "Beobachtungen an einer Süsswasser Peridinee." Journal Coll. Sci., Tokyo, vol. 32, 1911, pp. 77-92.

95. Oltmanns, F. " Morphologie und Biologie der Algen." Jena, 1904-5.

96. Ostenfeld, C. H. "Phreocystis Pouchetii and its zoospores." Archiv f. Protistenkunde, I3d. 3, 1904, pp. 295-302.

97. Pascher, A. "Studien über die Schwärmer einiger Süsswasseralgen." Bibliotheca Botanica, vol. 67, 1907.

$98 . \quad$,

"Pyramidochrysis, eine Gattung der Chrysomonaden." Berichte d. deutsch. bot. Ges., Bd. 27, 1909, pp. 555-562. 
99. Pascher, A. "Neue Chrysomonaden aus den Gattungen Chrysococcus; Chromulina, Uroglenopsis." Oesterr. bot. Zeitschr., Bd. 60, 1910, pp. 1.5 .

$100 . \quad$,

"Ueber einige Fälle vorübergehenden Koloniebildung bei Flagellaten." Ber. d. d. bot. Ges., Bd. 28, 1910, pp. 339-350.

101. , ,

"Chrysomonaden aus dem Hirschberger Grossteiche." Monograpien und Abhandlungen zur internat. Revue d. ges. Hydrobiologie u. Hydrographie, Band 1, 1910 ; $66 \mathrm{pp}$.

$102 . \quad$,

"Cyrtophora, eine neue tentakeltragende Chrysomonade aus Franzensbad und ihre Verwandten." Ber. d. d. bot. Ges., Bd. 29, 1911, pp. 112-125.

103.

"Zivei braune Flagellaten." Ibid, Bd. 29, 1911, pp. 190-192.

" Ueber die Beziehungen der Cryptomonaden zu den Algen." Ibid., Bd. 29, 1911, pp. 193-203.

105. , ,

"Marine Flagellaten im Susswasser." Ibid., Bd. 29, 1911, pp. 517-523.

106. , ,

"Ueber Nannoplankton des Susswassers." Ibid., Bd, 29, 1911, pp. 523-533.

$107 . \quad$,

"Scherffelia, eine neue Chlamydomonadine." Lotos, Naturwiss. Zeitschr., Prag, Bd. 59, 1911, pp. 341-3.

108. ", "Zur Kenntnis zweier Volvocalen." Hedwigia, Bd. 52, 1912, pp. 274-287.

109. ", "Eine farblose rhizopodiale Chrysomonade." Ber. d. deutsch. bot. Ges., Bd. 30, 1912, pp. 152-158.

$110 . \quad$,

"Ueber Rhizopoden-und Palmellastadien bei Flagellaten (Chrysomonaden)." Archiv f. Protistenkunde, Bd. 25,1912 , pp. $153 \cdot 200$.

111. ,

"Braune Flagellaten mit seitlichen Geisseln." Zeitschrift f. wiss. Zoologie, Bd. 100, 1912, pp. 177-189.

112. " "Die Heterolsontengattung Pssudotetraëdron." Hedwigia, Bd. 53, 1913, pp. 1-5.

113. ", "Zur Gleiderung der Heterokonten." Ibid., pp. 6-22.

114. Pavillard, J. "Recherches sur la Flore pélagique Phytoplanlston de l'Etang de Thau." Montpellier, 1905.

115. " "Etat actuel de la Protistologie végétale." Progressus rei botanicæ, Bd. 3, 1910, pp. 474-544.

116. Peebles, Florence. "The life history of Spherella lacustris." Centrabl. f. Bakteriologie, Bd. 24, Abt. 2, 1909, pp. 511-521.

117. Prowazek, S. von. "Kerntheilung und Vermehrung der Polytoma." Oesterr. bot. Zeitschrift, Bd. 51, 1910, pp. 51-60.

118.

"Untersuchungen über einigen parasitische Flagellaten." Arb. kais. Gesundheits-Amte, Bd. 21, 1904, p. 1.

119. Reichenow, E. "Untersuchungen an Hamatococcus puluvialis, nebst Bemerkungen über andere Flagellaten." Arb. kais. Gesunh.-Amte. Bd. 33, 1909; 45 pp.

120. Reinisch, Olga. " Eine neue Phæocapsacee." Ber. d. d. bot. Ges., Bd, 29, 1911, pp. 77-83.

121. Robertson, M. " "seudospora Volvocis." Q.J.M.S., vol. 49, 1905, p. 213.

122. Scherffel, A. "Phacocystis globosa nov. spec. nebst einigen Betrachtungen über die Phylogenie niederer insbesondere brauner Organismen" "Wiss. Meeresunter's., Helgoland, N.F.Bd. 4, 1900.

123. " "Kleiner Beitrag zur Phylogenie einiger Gruppen niederer Organsimen." Bot. Zeitung, Bd. 59, 1901, pp. 143-158.

124. ", "Notizen zur Kenntniss der Chrysomonadineae." Ber. d. deutsch, bot. Ges., Bd. 22, 1904, pp. 439-444.

125. " "Beitrag zur Kenntnis der Chrysomonadineen." Archiv für Protistenkunde, Bd. 22, 1911, pp. 299-344.

126. Schewiakoff, IV. "Ueber geographische Verbreitung der SüsswasserProtozoen.' Mem. de l'Acad. Imp. Sci. St. Peter'sburg, Sér. 7, T. 41, 1893.

127. Schilling, A. J. "Die Süssivasser-Peridincen." Flora, 1891; Inaug, Diss., Basel, 81 pp.

128.

"Untersuchungen über die thierische Lebensweise einiger Peridineen." Bef. d.deutsch. bot.Ges., Bd. 9, 1891, pp. 199-208, 
129. Schmidle, W. "Aus der Chlorophyceenflora der Torfstiche zu Viernheim." Flora, 1894.

130. ,

"Ueber Planktonalgen und Flagellaten aus dem Nyassasee." Engler's Bot. Jahrb., Bd. 27, 1899, p. 229.

131.

"Bemerkungen zu einigen Süssivasseralgen." Ber. d. deutsch. bot. Ges., Bd. 21, 1903, pp. 346-355.

132. Schroeder, B. "Das Phytoplankton des Golfes von Neapel." Mitt. Zool. Stat. Neapel, Bd. 14, 1901.

133. Schussnig, B. "Beitrag zur Kenntnis von Gonium pectorale." Oesterr. bot. Zeitschrift, Bd. 61, 1911, pp. 121-6.

134. Schütt, F. "Peridiniales," in Engler und Prant1, Nat. Pflanzenfamilien, Teil 1, Abt. 1b, 1896.

135. Senn, G. "Flagellata" in Engler u. Prantl, Nat. Pflanzenfam., Teil 1, Abt. 1a, 1900 ; 96 pp.

136. " "Oxyrrhis, Nephroselmis, und einige Euflagellaten nebst Bemerkungen über deren System." Zeitschr. f. wiss. Zoologie, Bd. 97, 1911, pp. 605-672.

137. Serbinow, J. L. "Ueber eine neue pyrenoidenlose Race von Chlamydomonas stellata Dill." Bull. jard. imp. bot., St. Petersburg, t. 2, livr. 5, 1902.

138. Shaw, IV. R. "Pleodorina, a new genus of the Volvocineae." Bot. Gazette, vol. 19, 1884, p. 279.

139. Stein, F. “Der Organismus der Infusionstiere." Bd. 3, Leipzig, 1883.

140. Teodoresco, E. C. "Organisation et développement du Dunaliella, nouveau genre deVolvocacée-Polyblepharidée." Beih. z. Bot. Centralblatt, Bd. 18, 1905, pp. 215-232.

141.

"Observations morphologiques et biologiques sur le genre Dunaliella." Rev. gén de Botanique, t. 18, $1906,37 \mathrm{pp}$.

142.

"Matériaux pour la flore algologique de la Roumanie." Beih. z. Bot. Centralblatt, Bd. 21, Abt. 2, 1906-7, pp. 103-219.

143. Ulehla, V. "Die Stellung der Gattung Cy'athomonas From. im System der Flagellaten." Ber. d. deutsch. bot. Ges., Bd. 29, 1911 , pp. 284.292.

144. Vuillemin, P. “Les bases actuelles de la sy'stématique en mycologie." Progressus rei botanicae, Bd. 2, 1908.

145. Wesenberg-Lund, C. "Plankton investigations of the Danish lakes." Copenhagen, 1908.

146. West, G. S. "A treatise on the British freshwater Algre." Cambridge, 1904.

147. " " "On some critical Green Algæ." Journal Linnean Society, vol. 38, 1908, pp. 279-289.

148. " "The 'red snow' plant (Sphaevella nivalis.)" Journ. Royal Microscop. Soc., 1909, pp. 28-30.

149. Wille, N. "Chlorophycer" in Engler u. Prantl, Nat. Pflanzenfam., Teil. 1, Abt. 2, 1890.

150. " “Chlorophycere" Ibid., Nachträge zum Teil 1, Abt. 2, 1909

151. IVilley, A., and Hickson, S. J. "The Mastigophor"a," in "A Treatise on Zoology," ed. Sir Ray Lankester, Part 1, Fasc. 1; London, 1909.

152. Wollenweber, WV. "Das Stigma von Hamatococcus." Ber. d. deutsch. bot. Ges., Bd. 25, 1907, pp. 316-321.

153. " " "Untersuchungen über die Algengattung Hematococcus." Ibid., Bd. 26, 1908, pp. 238-298.

154. Woloszynska, J. "Das Phytoplankton einiger javanischen Seen." Bull. int. Acad. Sci., Cracovie, 1912, pp. 649-704.

155. Zacharias, $O$. "Ueber den Bau der Monaden und Familienstocke von Uroglena Volvox." Zoolog. Anz., Bd. 17, 1894, pp. 353-357.

156.

" Uber Pseudopodienbildung bei einem Dinoflagellaten." Forsch. Bor. Biol. Stat., Plön, Teil 7, 1899.

157. Zederbauer, E. "Geschlechtliche und ungeschlechtliche Fortpflanzung von Ceratium Hirundinella." Ber. d. deutsch. bot. Ges., Bd. 22, 1904, pp. 1-8.

158. Zuelzer, M. "Ueber" Spirochate plicatilis Ehrbg. und deren Verwandschaftsbeziehungen." Archiv f. Protistenkunde, Bd. 24, 1911, pp. 1-59. 
1) URING the publication of the foregoing series of papers, two interesting new members of the Volvocales/ have been discovered and described, and as the descriptions of these forms came to the writer's notice too late for reference in the portion dealing with this group, a note concerning them is here appended.

West $\mathrm{t}^{1}$ has described under the name Scourfieldia complanata a form which bears exactly the same relationship to Chlamydomonas that Scherffelia does to Carteria. This organism has a strongly compressed body, with two long flagella springing from the notched "anterior" end (in progression the organism moves backwards, however); the single chloroplast is sub-campanulate but Hattened and has no pyrenoid; there is no stigma ("eye-spot,") and the life history is unknown.

Korschikoff ${ }^{2}$ gives the name Spermatozopsis exsultans to an organism which apparently belongs to the Polyblepharidacex, bearing much the same relationship to Pyramimonas that Chloromonas does to Chlamydomonas-for instance there is no pyrenoid. The body is capable of undergoing considerable "euglenoid " changes of shape, but is typically elongated and spirally twisted through nearly a whole turn; the posterior end is usually pointed, while the anterior end is rounded and bears four long flagella, or in some cases two only. The greater part of the body is occupied by the chloroplast, which lies on the convex side and usually extends to both ends of the body, though in some cases it is curved at the posterior end, while at the anterior end there is a well-marked "eye-spot"; there is no pyrenoid. No trace of a cell-wall could be detected, and the organism is apparently capable of greater "metabolic" changes of form than have been observed in any other member of the Polyblepharidaceæ. From the other members of the latter family Spermatozopsis differs in being bilaterally symmetrical, with a unilateral chloroplast, though in this respect it agrees with some of the Chlamydomonads-e.g., Chlamydomonas media and C. parietaria. Vegetative reproduction was observed to occur in the same manner as in Pyramimonas, consisting in longitudinal division into two daughter cells and taking place in the motile state. $321-331$.

'West, G. S. "Algological Notes." Journal of Botany, 1912, pp.

${ }^{2}$ Korschikoff, A. " Spermatozopsis exsultans nov. gen. et sp. aus der Gruppe der Volvocales." Ber. d. deutsch. bot. Ges., Band 31, 1913, pp. 174-183. 